\title{
NEW ZEALAND: COUNTRY REPORT ON HUMAN RIGHTS
}

\author{
Justice Susan Glazebrook, Natalie Baird and Sasha Holden*
}

\section{INTRODUCTION}

\section{A Background}

New Zealand is a constitutional monarchy, operating with a system of elected and independent government which creates law and "advises" the Crown. New Zealand inherited its system of government and lawmaking on becoming a British colony in 1840 and many of the features of New Zealand's constitution continue to reflect the influence of British colonisation, despite legal independence. ${ }^{1}$ The Queen is Head of State and is represented in New Zealand by the GovernorGeneral. The three branches of New Zealand's government are the legislature, the executive and the judiciary. New Zealand operates with a unicameral Parliament, and therefore without the "checks and balances" on the exercise of executive power that a second house might offer. However, following a referendum in 1993, a mixed-member proportional system of government was introduced, increasing influences on decision making and restricting the power of the executive branch of government. ${ }^{2}$

\section{B Constitutional Structure and the Protection of Rights}

New Zealand does not have a single document that can be identified as "the constitution". ${ }^{3}$ Rather, its constitutional framework is discernable from a range of sources such as legislation, ${ }^{4}$

* Justice Susan Glazebrook of the Court of Appeal (with the assistance of Jane Standage - Education, Environment); Natalie Baird of the University of Canterbury School of Law (Rule of Law, Culture and Language); and Sasha Holden then of the Victoria University of Wellington School of Law (Introduction, Health) collaborated in preparing this report. Each author takes individual responsibility for their part of the Report, and the authors do not necessarily endorse the views in other parts of the Report. The views expressed in the Report are not to be taken as the views of the Court of Appeal or of the New Zealand Government.

1 The Statute of Westminster 1931, adopted by New Zealand in 1947, heralded New Zealand's independence.

2 See Geoffrey Palmer and Matthew Palmer Bridled Power - New Zealand's Constitutional Government (Oxford University Press, Auckland, 2004) 9-21.

3 See Matthew Palmer "What is New Zealand's Constitution and Who Interprets it? Constitutional Realism and the Importance of Public Office-Holders" (2006) 17 Public Law Review 133. 
common law, the Treaty of Waitangi, ${ }^{5}$ constitutional conventions, letters patent and in historic laws which arose out of New Zealand's earlier relationship with the United Kingdom. ${ }^{6}$ New Zealand's constitution does not have status as supreme law, and laws which are inconsistent with constitutional principles cannot be struck down by the courts. In addition, the constitution is flexible and, as a result, constitutional change can occur easily in New Zealand. ${ }^{7}$

Similarly, rights protections in New Zealand have developed in a piecemeal manner. The New Zealand Bill of Rights Act 1990 (BORA) was enacted to affirm, protect and promote human rights and fundamental freedoms, and to affirm New Zealand's commitment to the International Covenant on Civil and Political Rights (ICCPR). ${ }^{8}$ Arguably New Zealand's most significant domestic rights statute, BORA applies to the actions of the legislature, executive and judiciary and to "any person or body in the performance of any public function, power or duty conferred or imposed on that person or body by or pursuant to law." ${ }^{9}$ BORA is not entrenched, nor is it able to be used by the judiciary to strike down laws which are incompatible with it. ${ }^{10}$

However, despite its weaknesses, BORA does provide a mechanism to restrict the decision making power of the executive and the Attorney-General must report to Parliament where any Bill introduced to the House appears to be inconsistent with any of the rights and freedoms in the Bill of Rights. ${ }^{11}$ BORA is also used by the judiciary as an interpretive tool to ensure that other enactments are interpreted consistently with the rights and freedoms it protects, provided a consistent interpretation is possible. ${ }^{12}$ BORA provides legislative confirmation of fundamental civil rights in New Zealand and citizens are increasingly aware of, and prepared to use, BORA to check the actions of the Government and other bodies exercising public functions.

4 For example, the Constitution Act 1986, New Zealand Bill of Rights Act 1990, the Judicature Act 1908, the Electoral Act 1993, the Ombudsmen Act 1975, the Privacy Act 1993 and the Official Information Act 1982.

5 The Treaty of Waitangi 1840 is regarded by many as New Zealand's founding constitutional document, although its precise meaning and legal status are debated.

6 For example, the Magna Carta 1297, the Petition of Right 1627 and the Bill of Rights 1688. See the Imperial Laws Application Act 1988.

7 Palmer and Palmer, above n 2, 5.

8 International Covenant on Civil and Political Rights (16 December 1966) 999 UNTS 171 [ICCPR], affirmed in the BORA Long Title.

9 BORA, s 3(b).

10 Ibid, s 4.

11 BORA, s 7. Bills are subject to BORA vetting by the Ministry of Justice or the Crown Law Office in preparation for the Attorney-General's report. For further discussion, see Claudia Geiringer "The Dead Hand of the Bill of Rights? Is the New Zealand Bill of Rights Act 1990 a Substantive Legal Constraint on Parliament's Power to Legislate?" (2007) 11 Otago L Rev 389.

12 BORA, s 6 
As well as BORA, the Human Rights Act 1993 (HRA) is the current statute protecting against unlawful discrimination. ${ }^{13}$ The main purpose of the HRA is to provide protection against and remedies for unlawful discrimination on a wide range of grounds including sex, marital status, religious belief, race, disability, age, political opinion, employment status, family status and sexual orientation. ${ }^{14}$ Part 2 of the HRA prohibits discrimination in the private sphere. Part 1A provides a procedural vehicle for complaints against discrimination in the public sphere that are unlawful by virtue of section 19 of BORA. The HRA also authorises the work of the Human Rights Commission, which has been established to advocate and promote respect for human rights and encourage harmonious relations in New Zealand society. ${ }^{15}$

Other enactments with rights implications include the Official Information Act 1982 (regarding freedom of information), the Privacy Act 1993 (promoting individual privacy), ${ }^{16}$ the Ombudsmen Act 1975 (regarding executive responsibility), the Treaty of Waitangi Act 1975 (under which Treaty claims are administered), the Crimes of Torture Act 1989 and the Abolition of the Death Penalty Act 1989.

\section{The Courts}

The judiciary operates with a clear hierarchy of municipal courts. The Supreme Court sits at the top of the judicial order, above the Court of Appeal and the High Court. The High Court is a court of first instance as well as having some appellate functions from the District Court. Other courts of first instance include the District Court (including its family and youth divisions), the Environment Court, the Employment Court, and the Māori Land Court. There are a number of specialist tribunals including the Human Rights Review Tribunal (HRRT).

The judiciary is regularly asked to ensure the implementation of rights guarantees under domestic legislation and judges have indicated their inclination to ensure the enjoyment of basic human rights in New Zealand, regardless of the legal and constitutional forms in which they appear. ${ }^{17}$ Claims related to breaches of BORA may be made in association with a wide range of

13 Legislative human rights protections existed previously in the Human Rights Commission Act 1977 and the Race Relations Act 1971.

14 The prohibited grounds of discrimination are set out in detail at HRA, s 21.

15 For further information on the Human Rights Commission and human rights in New Zealand, see Human Rights Commission Human Rights in New Zealand Today - Nga Tika Tangata O Te Motu Whakarapopotanga (Human Rights Commission, Wellington, 2004) [Human Rights Today].

16 The Privacy Act 1993 is primarily concerned with personal information handling practices. However, a separate tort regarding invasion of privacy has arisen as part of New Zealand common law. In Hosking $v$ Runting [2005] 1 NZLR 1 (CA) the reasoning of the majority in favour of creating this new tort was linked closely to international human rights obligations.

17 Simpson v Attorney-General (Baigent's Case) [1994] 3 NZLR 667, 702 (CA). 
litigation matters in a variety of courts and tribunals. Complaints under the HRA are first sought to be mediated with the assistance of the Human Rights Commission. Where this is unsuccessful, complaints may be taken to the HRRT and complainants may apply to the Office of Human Rights Proceedings for legal representation.

\section{Civil Society}

New Zealand has a well developed and active civil society involved in supporting human rights and lobbying the Government regarding human rights matters. Civil society groups stem from both international non-governmental organisations (NGOs) such as Amnesty International and local initiatives, such as the Human Rights Foundation of Aotearoa New Zealand. Civil society is increasingly taking an active role in human rights public interest litigation in New Zealand.

\section{E Ratification of International Human Rights Guarantees}

New Zealand has long played an active role in the development of international human rights norms ${ }^{18}$ and has ratified seven of the nine core international human rights treaties, among other international human rights guarantees:

\begin{tabular}{|l|l|l|l|}
\hline \multicolumn{1}{|c|}{ Treaty } & \multicolumn{1}{|c|}{ In Force } & \multicolumn{1}{|c|}{$\begin{array}{c}\text { NZ Signature } \\
\text { Date }\end{array}$} & $\begin{array}{c}\text { NZ Ratification } \\
\text { Date }\end{array}$ \\
\hline $\begin{array}{l}\text { International Covenant on } \\
\text { Civil and Political Rights } \\
\text { (ICCPR) }\end{array}$ & 23 March 1976 & 19 December 1966 & 28 December 1978 \\
\hline $\begin{array}{l}\text { ICCPR } 1^{\text {st }} \text { Optional } \\
\text { Protocol (regarding } \\
\text { individual } \\
\text { communications) }\end{array}$ & 23 March 1976 & 19 December 1966 & 26 May 1989 \\
\hline $\begin{array}{l}\text { ICCPR 2 } \\
\text { Protocol Optional (aiming at the } \\
\text { abolition of the death } \\
\text { penalty) }\end{array}$ & 11 July 1991 & 15 December 1989 & 22 February 1990 \\
\hline $\begin{array}{l}\text { International Covenant on } \\
\text { Economic Social and } \\
\text { Cultural Rights (ICESCR) }\end{array}$ & 3 January 1976 & 19 December 1966 & 28 December 1978 \\
\hline
\end{tabular}

18 For further information on New Zealand's contribution to the development of international human rights law see M Bell "New Zealand's Contribution to the Early Post-War Development of International Human Rights (1998) 4 HRLP 147; C Aikman "New Zealand and the Origins of the Universal Declaration" (1999) 29 VUWLR 1; H Fawthrope "Human Rights" in M Templeton (ed) New Zealand as an International Citizen, Fifty Years of United Nations Membership (Ministry of Foreign Affairs and Trade, Wellington, 1995); R Q Quentin-Baxter "International Protection of Human Rights" in K Keith (ed) Essays on Human Rights (Sweet \& Maxwell, Wellington, 1968) 132. 


\begin{tabular}{|c|c|c|c|}
\hline $\begin{array}{l}\text { International Covenant on } \\
\text { the Elimination of Racial } \\
\text { Discrimination (CERD) }\end{array}$ & 4 January 1969 & 7 March 1966 & $\begin{array}{l}22 \text { November } \\
1972\end{array}$ \\
\hline $\begin{array}{l}\text { International Covenant on } \\
\text { the Elimination of } \\
\text { Discrimination Against } \\
\text { Women (CEDAW) }\end{array}$ & 3 September 1981 & 18 December 1979 & 10 January 1985 \\
\hline $\begin{array}{l}\text { CEDAW Optional } \\
\text { Protocol (regarding } \\
\text { individual } \\
\text { communications) }\end{array}$ & 22 December 2000 & 6 October 1999 & 7 December 2000 \\
\hline $\begin{array}{l}\text { Convention on the Rights } \\
\text { of the Child (CRC) }\end{array}$ & 2 September 1990 & $\begin{array}{l}20 \text { November } \\
1989\end{array}$ & 6 April 1993 \\
\hline $\begin{array}{l}\text { CRC Optional Protocol } \\
\text { (regarding children in } \\
\text { armed conflict) }\end{array}$ & 12 February 2002 & 25 May 2000 & $\begin{array}{l}12 \text { November } \\
2001\end{array}$ \\
\hline $\begin{array}{l}\text { CRC Optional Protocol } \\
\text { (regarding child } \\
\text { prostitution and } \\
\text { pornography) }\end{array}$ & 18 January 2002 & 7 September 2000 & Not ratified by NZ \\
\hline $\begin{array}{l}\text { Convention Against } \\
\text { Torture and Other Cruel, } \\
\text { Inhuman and Degrading } \\
\text { Treatment (CAT) }\end{array}$ & 26 June 1987 & 10 December 1954 & 10 December 1989 \\
\hline $\begin{array}{l}\text { CAT Optional Protocol } \\
\text { (regarding monitoring of } \\
\text { detention facilities) }\end{array}$ & 22 June 2006 & 18 December 2002 & 14 March 2007 \\
\hline $\begin{array}{l}\text { International Convention } \\
\text { on the Protection of the } \\
\text { Rights of All Migrant } \\
\text { Workers and Members of } \\
\text { their Families (CMW) }\end{array}$ & 1 July 2003 & Not signed by NZ & Not ratified by NZ \\
\hline $\begin{array}{l}\text { Convention on the Rights } \\
\text { of Persons with } \\
\text { Disabilities }\end{array}$ & 3 May 2008 & 30 March 2007 & $\begin{array}{l}25 \text { September } \\
2008\end{array}$ \\
\hline $\begin{array}{l}\text { Optional Protocol to the } \\
\text { Convention on the Rights } \\
\text { of Persons with } \\
\text { Disabilities }\end{array}$ & 3 May 2008 & Not signed by NZ & Not ratified by NZ \\
\hline $\begin{array}{l}\text { International Convention } \\
\text { for the Protection of All } \\
\text { Persons from Enforced } \\
\text { Disappearance }\end{array}$ & $\begin{array}{l}\text { Adopted by the } \\
\text { UN General } \\
\text { Assembly } 20 \\
\text { December 2006; } \\
\text { not yet in force }\end{array}$ & Not signed by NZ & Not ratified by NZ \\
\hline
\end{tabular}




\section{F Legal Status of International Human Rights Treaties}

The authority to take binding treaty action rests with the executive. However, since 1998, multilateral human rights treaties are presented to the legislature for consideration before binding treaty action is taken ${ }^{19}$ and, if needed, legislation is introduced to ensure domestic adherence to the treaty terms. ${ }^{20}$

The manner in which international treaties interact with New Zealand's domestic legal system continues to evolve. New Zealand has traditionally operated according to a "dualist" model of international treaty incorporation, meaning that international treaties are not directly enforceable in domestic courts unless Parliament has enacted specific legislation to give the relevant treaty domestic force of law. In addition, it is only to the extent that the wording of the domestic statute brings the text of an international treaty into domestic law that the terms of the original treaty are domestically binding. For example, the purpose of BORA is, in part, to affirm New Zealand's commitment to the ICCPR. ${ }^{21}$ However, not all of the rights contained in the ICCPR are included in BORA, and only those that are included can be enforced directly in New Zealand's municipal courts.

\section{G Judicial Response to International Human Rights Treaties}

Despite New Zealand's traditionally dualist position in relation to international human rights treaties, domestic courts have increasingly indicated their intention to have regard to international treaties without the need for direct legislative incorporation. This trend is particularly evident in the human rights area. Case law indicates the judiciary's desire to ensure that New Zealand's international human rights obligations are not mere "window dressing" where they are not directly incorporated into domestic legislation. ${ }^{22}$

19 The procedure is set out at the Cabinet Manual 2008 paras 7.111-7.122 and also in the Standing Orders of the House of Representatives 2005 SO 387-390.

20 For a summary of domestic compliance with international treaty obligations, see the multilateral agreements database www.justice.govt.nz/pubs/reports/1996/agreements/part3sec4.htm (accessed 20 February 2008).

21 BORA Long Title.

22 Tavita v Minister of Immigration [1994] 2 NZLR 257, 266 (CA) Cooke P. For an early description of the relationship between international law and domestic law in New Zealand see Andrew Butler and Petra Butler "The Judicial Use of International Human Rights Law in New Zealand" (1999) VUWLR 173. For a detailed discussion of the current interaction between international treaty obligations and New Zealand's domestic law, see Claudia Geiringer "International Law through the Lens of Zaoui: Where is New Zealand At?" (2006) 17 PLR 300. 


\section{Legal and administrative remedies for breaches of BORA}

New Zealand courts may award monetary compensation where a breach of BORA is successfully argued, despite the absence of an express provision regarding remedies in the Act. ${ }^{23}$ Stays of proceedings ${ }^{24}$ and the exclusion of evidence ${ }^{25}$ may also be available where a breach of BORA has occurred. In addition, although an offending law cannot be "struck down" because of a conflict with BORA, the courts have reasoned that BORA provides them with the power to indicate the legal inconsistency of an offending statute where it conflicts with the rights protections guaranteed by BORA. ${ }^{26}$ It is worth noting, however, that despite such comments by the courts, the courts have not yet issued a "declaration of inconsistency" in nearly twenty years of BORA jurisprudence. ${ }^{27}$ Nevertheless, the theoretical availability of the declaration as a remedy indicates that legal challenges to Government action using BORA have the potential to result in changes to the law and may encourage modifications in executive behaviour. ${ }^{28}$

\section{Legal and administrative remedies for breaches of HRA}

More general discrimination protection is provided in the HRA and a range of remedies is available. These include a declaration confirming that a breach of the HRA has occurred, an order restraining or requiring certain behaviour, an order for damages and any other relief the HRRT may

23 Baigent's Case, above n 17. See also Taunoa v Attorney-General [2008] 1 NZLR 429 which sets out principles for the award of compensation for BORA breaches. For further reading, see Rishworth et al The New Zealand Bill of Rights (Oxford University Press, Melbourne, 2003) ch 29.

24 For example Martin v District Court at Tauranga [1995] 2 NZLR 419 (CA); Du v District Court of Auckland (2005) 22 CRNZ 505; Graham v District Court at Blenheim [2007] NZAR 32 (HC).

25 Evidence Act 2006 s 30 provides a statutory basis for the exclusion of improperly obtained evidence, including that obtained in consequence of a breach of BORA. A balancing process is used to determine whether the exclusion of evidence is proportionate to the impropriety. The section codifies, modifies, and extends the balancing process set out in $R v$ Shaheed [2002] 2 NZLR 377 (CA). For guidance on a framework to apply the balancing process, see $R v$ Williams [2007] 3 NZLR 207.

26 Cases where the courts have said it is open to them to make such an indication under BORA include Moonen v Film \& Literature Board of Review [2003] 2 NZLR 9 (CA), para 20; $R$ v Poumako [2002] 2 NZLR 695, 716; Zaoui v Attorney-General [2004] 2 NZLR 339 (CA), para 172. For the principles to be used in making such declarations, see $R v$ Hansen [2007] 3 NZLR 1 (SC) and Belcher $v$ Chief Executive of Department of Corrections [2007] 1 NZLR 507 (CA); approved in Belcher $v$ Chief Executive of Department of Corrections [2007] NZSC 54 (CA). For further information see Rishworth et al, above n 23, 834, and Andrew Butler and Petra Butler The New Zealand Bill of Rights Act: a Commentary (LexisNexis, Wellington, 2005) 1017.

27 See discussion below in relation to the first declaration of inconsistency made by the Human Rights Review Tribunal in Howard v Attorney-General [2008] NZHRRT 10 (15 May 2008).

28 For a critical discussion of the Supreme Court's Hansen case see Claudia Geiringer "The Principle of Legality and the Bill of Rights Act: A critical examination of $R v$ Hansen" (2008) NZJPIL 59. 
consider appropriate; ${ }^{29}$ see the discussion below on public interest litigation under the HRA and the "declaration" remedy.

3 Other remedies

Citizens can, and frequently do, ask the New Zealand courts to evaluate executive action by way of judicial review. ${ }^{30}$ In addition, for breaches of international human rights guarantees, individuals may use the complaints mechanisms provided in the ICCPR, CAT and CEDAW treaties. However, it is noteworthy that New Zealand has not made a declaration under article 14 of CERD, meaning individuals cannot take complaints against New Zealand to the CERD Committee.

\section{$4 \quad$ Non-judicial rights protections}

In addition to the availability of judicial remedies regarding human rights matters, New Zealand has a range of non-judicial mechanisms for rights protection. The Human Rights Commission provides mediation services for human rights disputes and is also responsible for the adoption of national plans of action and human rights education and awareness-raising. Further support for rights protections is provided by the Privacy Commissioner, the Ombudsman's Office, the Health and Disability Commissioner and the Children's Commissioner. ${ }^{31}$

\section{RULE OF LAW}

Rule of law is an ambiguous concept, depending on the context in which it is used. In today's world, it is often used in a rhetorical and aspirational sense, "operating as shorthand for the ideals that identify the liberal democracy." 32 At its core though, the rule of law means the absence of arbitrary power, with the courts regarded as the ultimate guardians of the rule of law. In this paper, the following elements of the rule of law are discussed: separation of powers, judicial independence, and access to open and transparent justice. Other important elements include the accountability of public officials (government according to law) and the accessibility of processes for enacting, administering and enforcing laws. ${ }^{33}$

29 HRA, s 92I.

30 Butler and Butler, above n 26, 1072 .

31 For further information on rights protections in New Zealand see Butler and Butler, above n 26; Rishworth et al, above n 23; and Huscroft and Rishworth (eds) Rights and Freedoms: The New Zealand Bill of Rights Act 1990 and the Human Rights Act 1993 (Brookers, Wellington, 1995).

32 Philip A Joseph Constitutional and Administrative Law in New Zealand (Thomson Brookers, Wellington, 2007) 152.

33 An important recent initiative in this area is the World Justice Project. This project involves national and international law associations dedicated to promoting the rule of law internationally. See www.abanet.org/wjp/ (accessed 1 April 2008). 


\section{A Separation of Powers}

Although the "separation of powers" doctrine is an important feature of the New Zealand system, in common with other Westminster parliamentary systems, there is a fusion of the executive and legislative branches. Membership of Parliament is a prerequisite for appointment as a member of the executive (a Government Minister), meaning that the separation of executive and legislative power is blurred at the margins. Under the first-past-the-post (FPP) voting system, single-party majority governments were the norm. There was much criticism that the legislature was subordinate to the executive under FPP, such that one commentator described New Zealand as having "the fastest law-maker in the West." 34 The introduction of the mixed member proportional (MMP) voting system in 1996 has gone some way towards restoring the balance between the executive and legislative branches, such that executive control over Parliament has now lessened. ${ }^{35}$

\section{B Judicial Independence}

A key aspect of the separation of judicial power from the two political branches is the fundamental principle of judicial independence. Judicial independence is strong in New Zealand although there are occasionally tensions around the edges. In terms of appointment of judges, new procedures were introduced in 1999, making the Attorney-General responsible for most appointments. For example, appointment of judges to the High Court, Court of Appeal and Supreme Court is made by the Governor-General on behalf of the Queen, acting on the advice of the Attorney-General (or the Prime Minister, in the case of the Chief Justice). By constitutional convention, the Attorney-General does not discuss appointments at Cabinet, but does consult with the Solicitor-General, the Chief Justice, the President of the Court of Appeal and the Presidents of the Law Commission, New Zealand Law Society and the New Zealand Bar Association.

The constitutional convention of non-partisan independent judicial appointments is a strong one. To date, judicial appointments have generally been free of any suggestion of improper political considerations. This includes the appointment of the first Supreme Court bench in 2003 where concern had been expressed that the opportunity of appointing the full bench at one time would be exploited for political purposes. Concern has, however, been expressed that the makeup of the judiciary does not reflect the full diversity of New Zealand society. It has also been noted that calls from the community for increased accountability of judges are partly based on suspicion attached to decisions made by judges who are not representative of society. ${ }^{36}$

34 Geoffrey Palmer Unbridled Power: An interpretation of New Zealand's Constitution and Government (Oxford University Press, Wellington, 1979) 77.

35 Palmer and Palmer, above n 2, ix.

36 Ibid, 295. For concerns about the appointment of the Supreme Court bench see New Zealand Business Roundtable Submission on the Supreme Court Bill (May 2003) at www.nzbr.org.nz (accessed 4 February 
Although there is a prescribed retirement of age of 70 for judges, ${ }^{37}$ once they are in office, section 23 of the Constitution Act 1986 protects judges from removal from office except on grounds of misbehaviour or incapacity. Section 24 provides that salaries of judges are not to be reduced during their term of office. On appointment to office, judges take an oath or affirmation that they will "do right to all manner of people after the laws and usages of New Zealand without fear or favour, affection or ill will."

In order to deal with situations of improper judicial conduct, in 2004 Parliament passed the Judicial Conduct Commissioner and Judicial Conduct Panel Act. The Office of the Judicial Conduct Commissioner was established in 2005 to deal with complaints about the conduct of judges. The aim is to enhance public confidence in the judiciary, while at the same time protecting the impartiality and integrity of the judicial system. The Judicial Conduct Commissioner cannot challenge the legality or correctness of a judge's decision in relation to any legal proceedings, but can consider complaints about judges' conduct both inside and outside court. ${ }^{38}$

In terms of the relationship between the judiciary and the other branches, the Cabinet Manual sets out guidelines for Government Ministers in commenting on judicial decisions. It calls on Ministers to exercise prudent judgment before commenting on judicial decisions. ${ }^{39}$ In Parliament, the Standing Orders limit the ability of members to comment on matters awaiting or under adjudication, and prohibit the use of offensive words against any member of the judiciary. ${ }^{40}$ On the other side, judges do not involve themselves in political activities, and in matters of political controversy, they are required to avoid taking public sides. ${ }^{41}$

In recent years, some tension has been apparent between the judiciary and the political branches. In 2004, Elias CJ made some comments on parliamentary sovereignty, the lack of judges' institutional independence, and the siting of the new Supreme Court building. There were subsequent public exchanges between the Prime Minister and Deputy Prime Minister on the one hand and the Chief Justice on the other. ${ }^{42}$ Of particular note is the tension inherent in the role of

2009). For concerns about cultural diversity in the New Zealand judiciary see Catriona MacLennan "Cast the net wider for effective judges" New Zealand Herald (9 May 2004).

37 Judicature Act 1908, s 13

38 For more information about this process, see www.jcc.govt.nz (accessed 12 March 2008).

Cabinet Manual 2008 paras 4.12-4.15

Standing Orders 2005 SO 111-113.

41 Palmer and Palmer, above n 2, 297.

42 See P A Joseph "The Higher Judiciary and the Constitution: A View from Below" in Rick Bigwood (ed) Public Interest Litigation: New Zealand Experience in International Perspective (LexisNexis, Wellington, 2006) 213, 219-222; Stephen Franks "Political Criticism of Judges" [2004] NZLJ 11; and Thomas Gibbons "Criticising judges: further comments" [2004] NZLJ 245. 
judges in promoting the rule of law in the context of the doctrine of parliamentary sovereignty. This is illustrated by the foreshore and seabed issue. In this case, the Court of Appeal held that the Mãori Land Court had jurisdiction to consider claims to customary title to foreshore and seabed, although actual award of title would depend on whether it could be established in the facts of the particular case. ${ }^{43}$ Parliament subsequently enacted the Foreshore and Seabed Act 2004 to essentially overturn the Court's decision. While Parliament is entitled to overturn judicial decisions, and this is a legitimate manifestation of the doctrine of parliamentary sovereignty, this decision left many with a strong sense of unease. ${ }^{44}$ In terms of the wider unresolved tension between rule of law and untrammelled legislative power, views on either side of the debate are strong. ${ }^{45}$ One academic commentator has argued that the rule of law is "a new and deserving contender for the ultimate principle of the constitution" 46 and might at some point displace legislative supremacy as the basis of legality.

\section{Access to Justice}

\section{Right to legal aid}

Section 24(f) of BORA guarantees the right, when charged with a criminal offence, "to receive legal assistance without cost if the interests of justice so require and the person does not have sufficient means to provide for that assistance." Section 24(f) is closely connected with other rights including sections 23(1)(b) and 24(c) guaranteeing the right to a lawyer, section 24(d) guaranteeing adequate time and facilities to prepare a defence, and the overarching right to a fair trial in section 25(a).

The right to legal aid has not been subject to much litigation, in part because the Legal Services Act 2000 sets out a comprehensive scheme for legal assistance in criminal and civil cases. ${ }^{47}$ In criminal cases, legal aid is available in most proceedings ${ }^{48}$ to those who meet the financial criteria and in respect of whom it can be said that the "interests of justice" require the provision of legal assistance. ${ }^{49}$ Legal aid is also available in many civil proceedings, ${ }^{50}$ although the criteria to be met

43 Attorney-General v Ngati Apa [2003] 3 NZLR 643.

44 See Claire Charters "An Imbalance of Power: Māori Land Claims and an Unchecked Parliament" (2006) 30(1) Cultural Survival Quarterly; Claire Charters "Responding to Waldron's Defence of Legislatures: Why Parliament cannot Protect Rights in Hard Cases" (2006) 5 NZ Law Rev 621.

45 For example Michael Cullen "Parliamentary Sovereignty and the Courts" [2004] NZLJ 243 and Sian Elias "The Next Revisit: Judicial Independence Seven Years On" (2004) 10 Canta LR 217.

46 Joseph, above n 32, v.

47 Butler and Butler, above n 26, para 22.7.1.

48 Legal Services Act 2000, s 6.

49 Ibid, s 8. 
are stricter and include a requirement on the applicant to show reasonable grounds for taking or defending the proceedings and whether the repayment amount will exceed the cost of proceedings. ${ }^{51}$

The right in section 24(f) is a right "to receive legal assistance without cost." A variety of systems will potentially satisfy this obligation, and in addition to the funding of legal aid, the Legal Services Agency runs other initiatives. It facilitates "initial criminal legal services" via the Duty Solicitor Scheme and the Police Detention Legal Assistance Scheme. The Legal Services Agency has also piloted a Public Defence Service in the Auckland and Manukau courts since May 2004.

A number of issues concerning legal aid have arisen recently. The financial eligibility criteria were lowered in March 2007 for both civil and criminal matters to increase eligibility. At the same time, a new repayment and debt management system was introduced. Criminal and civil legal aid recipients are now treated in a similar way meaning that more criminal aid recipients will be required to contribute to their legal costs. Concern has, however, been expressed as to the overall impact these changes may have on access to justice: that what was given with one hand (greater eligibility) may have been taken away with the other (requirements to repay). The New Zealand Law Society, and criminal legal aid lawyers in particular, have also strongly expressed their concerns that the prescribed fees for lawyers taking on legal aid clients are too low. ${ }^{52}$ A review of remuneration rates for legal aid lawyers was begun in 2007, and the proposed increase of 15.9 per cent is considered derisory by many lawyers. ${ }^{53}$ There is a concern that some legal aid lawyers may opt out of providing legal aid services, with detrimental impact on access to justice.

In its 2007 comments on New Zealand's sixth periodic report under CEDAW, ${ }^{54}$ the CEDAW Committee noted its concern about the barriers women faced in accessing legal aid and seeking redress in the courts and about the level of awareness among women of their rights, remedies and services. In particular, the Committee was concerned about whether women were adequately aware of their rights under the Property (Relationships) Act $1976 .{ }^{55}$

$50 \quad$ Ibid, s 7

51 Ibid, s 9.

52 "Legal aid rates - trenchant NZLS criticism" LawTalk 685 (23 April 2007); "Legal aid remuneration concerns MPs" LawTalk 692 (30 July 2007); "Legal aid - recommended rates not enough, NZLS says" LawTalk 698 (29 October 2007); "Frequent rate reviews 'vital' to legal aid system" LawTalk 704 (14 March 2008).

53 Darise Ogden "Please, sir, can I have some more?" NZLawyer (22 February 2008) 22-23.

54 Convention on the Elimination of all Forms of Discrimination Against Women (18 December 1979) 1249 UNTS 13 [CEDAW]

$55 \mathrm{CEDAW} / \mathrm{C} / \mathrm{NZL} / \mathrm{CO} / 6$ (2007) para 40. 


\section{Public interest litigation}

Public interest litigation ${ }^{56}$ is still relatively novel in New Zealand, although its use has increased in recent years. Recent examples of public interest litigation include the 1980s cases concerning New Zealand's rugby contacts with apartheid South Africa, ${ }^{57}$ an unsuccessful attempt to argue that the Marriage Act permitted marriage between same-sex couples, ${ }^{58}$ and a challenge to a Government special education policy that aimed to mainstream children with disabilities and disestablish targeted facilities. ${ }^{59}$ The string of cases brought by the New Zealand Māori Council and iwi in the late 1980s and early 1990s to assert Māori rights under the Treaty of Waitangi are a prominent example of public interest litigation. ${ }^{60}$

More recently, in the area of unlawful discrimination under the HRA, the door has been opened for public interest litigation. When the HRA was first enacted in 1993, it expressly provided that nothing in the Act limited or affected the provisions of any other Act or regulation. ${ }^{61}$ The Human Rights Amendment Act 2001 introduced Part 1A to the HRA, and with it the possibility of challenging legislative action on the grounds of unlawful discrimination. The only remedy is a declaration of inconsistency. ${ }^{62}$ Such a declaration does not affect the validity of the enactment in question, but does require the responsible Minister to report to Parliament on the Government's response to the declaration. ${ }^{63}$ The HRRT made its first declaration of inconsistency in May 2008 finding that parts of the Injury Prevention Rehabilitation and Compensation Act 2001 were inconsistent with the right to be free from discrimination (in this case on the grounds of age) guaranteed in section 19 of BORA. ${ }^{64}$ As illustrated by this first successful case, Part 1A essentially enables complainants to challenge matters of a policy or political character.

An earlier 2006 landmark decision confirmed that the door definitely is open for public interest litigation in this area. The case, brought by the Child Poverty Action Group (CPAG), a children's

56 For a recent discussion of public interest litigation, see Bigwood, above n 42.

57 For a discussion of these cases, see Michael Taggart "Rugby, the Anti-apartheid Movement, and Administrative Law" in Bigwood, above n 42, 69-98.

58 Quilter v Attorney-General [1998] 1 NZLR 523 (CA).

59 Attorney-General v Daniels (2002) 16 PRNZ 331(HC); [2003] 2 NZLR 742 (CA).

60 See for example New Zealand Māori Council v Attorney-General [1987] 1 NZLR 641 (CA); Tainui Māori Trust Board v Attorney-General [1989] 2 NZLR 513 (CA); Te Runanga o Muriwhenua Inc v AttorneyGeneral [1990] 2 NZLR 641.

61 HRA, s 151.

62 HRA, s 92J(1).

63 HRA, s 92K(2).

64 Howard v Attorney-General [2008] NZHRRT 10 (15 May 2008). 
rights NGO, alleged that legislation containing child tax credits discriminated, on employment and family status grounds, against those on income tested benefits. In order to get this claim heard, CPAG first had to establish that it had standing to bring the claim even though it was not itself directly affected. After a protracted set of proceedings, the High Court eventually upheld CPAG's right to bring a claim. ${ }^{65}$

\section{Excessive delays in court proceedings}

An issue receiving some attention recently has been that of significant delays in resolving proceedings - particularly in criminal matters. Section 25(b) BORA provides that everyone charged with an offence has "the right to be tried without undue delay." At the systemic level, the average wait for a jury trial in the High Court from committal to trial date is 305 days, and for district court jury trials it is 283 days. In the past year, delays have resulted in a stay of proceedings in ten cases, including serious cases such as assault and kidnapping. ${ }^{66}$ A recent case also allowed sentence reduction for undue delay. ${ }^{67}$ Excessive delays in criminal proceedings raise issues of fairness to both the defendant and the victim. The public also has an interest in seeing a person accused of a crime brought to trial. In June 2008, Parliament passed the Criminal Procedure Bill which contains a number of procedural reforms aimed in part at addressing issues of efficiency in the justice system. ${ }^{68}$

This issue of delay has also received attention in the Family Court context. In $E B v$ New Zealand, ${ }^{69}$ the Human Rights Committee, in its second finding against New Zealand, found that there had been a violation of Article 14 of the ICCPR. Mr EB brought a claim alleging that New Zealand had violated Articles 2, 14, 17, 23, 24 and 26 of the ICCPR in the denial of access by EB to his children after prolonged access proceedings in the Family Court. In its decision, the Human Rights Committee said that New Zealand had an onus to ensure that all state actors involved in family proceedings are sufficiently well resourced to ensure prompt resolution of such proceedings. The Committee concluded that New Zealand had not demonstrated the justification for the

65 See Attorney-General v Human Rights Review Tribunal (2006) 18 PRNZ 295 (Miller J). In the substantive hearing of the CPAG case, the HRRT concluded that the case did not warrant a declaration of inconsistency. See Child Poverty Action Group Inc v Attorney-General [2008] NZHRRT 31 (16 December 2008).

"Delay and Denial" The Press (22 January 2008). See for example $R v$ Williams HC AK CRI-2004-404-6 and CRC-2007-404-7 (10 August 2007) Asher J and $R v F$ HC CHCH CRI-2003-009-12476 (7 February 2008) Panckhurst J.

$67 R v$ Williams (6 December 2007) HC AK CRI-2007-404-6 Asher J. The case involved manufacture of methamphetamine, and the sentences of three accused were all reduced by 18 months because of the protracted delay (five years between arrest and trial).

68 The Bill amended the Crimes Act 1961, the Summary Proceedings Act 1957, the District Courts Act 1947, and the Juries Act 1981. It also created a new Criminal Disclosure Act 2008.

$69 E B v$ New Zealand CCPR/C/89/D/1368/2005 (views adopted 16 March 2007). 
protracted delay in the resolution of the access proceedings. However, the Committee went on to conclude that the Family Court's decision not to grant EB access to two of his children was not a violation of the father's rights under Articles 17 and 23 of the ICCPR.

Committee member Ms Ruth Wedgwood disagreed with the Committee's views that there was a violation of Article 14 ICCPR. Ms Wedgwood was of the view that the Committee had given insufficient weight to the wider factual context of the dispute including allegations that EB had sexually assaulted his children and therefore presented a serious danger to them. In her view, the potential gravity of harm to a child was some explanation for the delay in resolving the Family Court access proceedings. Also, the Committee failed to take account of the very real problems in case management which arise where there are parallel civil and criminal proceedings. She concluded that it was not appropriate for the Committee to "deride the conscientious attempt of the state party to reach a just result in this case."

In July 2007, the New Zealand Government responded to the Committee's views in $E B v N e w$ Zealand. The response stated that it did not accept that a breach of Article 14 had occurred. Instead the Government accepted the view of Ms Wedgwood that "the suggestion that this case could be handled quickly... does not give weight to the difficulty of assessing delicate facts in the close confines of a family and to the trauma to children that can be caused by the very process of investigation." 70 The response also noted that the Family Court was running a pilot called "Parenting Hearings Programme: Less adversarial children's hearings" aimed at resolving cases in a less adversarial manner, and reducing delay by shortening families' involvement in litigation. ${ }^{71}$ The Principal Family Court Judge also proposed "judicial registrars" for the Family Court to speed up hearings. ${ }^{72}$

\section{Police conduct}

A number of incidents in recent years have highlighted concerns about police conduct. In February 2004, a Commission of Inquiry into Police Conduct was established to carry out an investigation into the way in which New Zealand Police had dealt with allegations of sexual assault against members of the police and associates. The establishment of the Inquiry followed the publication of allegations made independently by two women suggesting that police officers might have deliberately undermined or mishandled investigations into complaints of sexual assault that had been made against other officers.

70 "United Nations Human Rights Committee - Communication No 1368/2005 submitted by EB: The New Zealand Government Response to the Views of the Human Rights Committee in relation to Communication 1368/2005" (July 2007) www.justice.govt.nz (accessed 17 October 2007).

71 Ibid, paras 19-21.

72 "Judicial registrars promoted for Family Court" LawTalk 704 (17 March 2008). 
The Inquiry released its report in March 2007, making sixty recommendations for change. ${ }^{73}$ The Inquiry did not comment on the guilt or innocence of individuals involved in the alleged offences, but focussed instead on how police responded to allegations of sexual assault against police, and whether people making allegations were treated appropriately. Matters covered in the Commission's report included standards and procedures for complaint investigations, police practice in complaint investigations, the role of the Police Complaints Authority, internal police disciplinary processes and the police code of conduct. Importantly, it was also noted that much of the Commission's focus was on historical matters (the inquiry dated back to matters occurring in 1979), and that there had been significant improvements in standards and practices over the period. In addition, during the three-year life of the Inquiry itself, there had been a number of positive developments including a police culture review to minimise improper behaviour and an "integrity project."

The recommendations of the Inquiry are being progressively implemented. A number of recommendations included enhancing the independence and effectiveness of the Police Complaints Authority. In September 2007, the Authority was reconstituted as the Independent Police Conduct Authority, with more resources and greater independence, ${ }^{74}$ and in December further proposals were announced to strengthen the Authority. ${ }^{75}$

In October 2007, around 300 police officers were involved in an anti-terrorist operation around the country, with search warrants executed in Auckland, Whakatane, Ruatoki, Hamilton, Palmerston North, Wellington and Christchurch. ${ }^{76}$ Sixteen people, including members of Māori sovereignty, environmental, peace and anarchist groups were arrested. They were charged with illegal possession of firearms under the Arms Act 1983, and the Police indicated that they would also lay charges under the Terrorism Suppression Act 2002. There was significant public protest at the operation, with concern at the heavy-handed tactics allegedly used by police, particularly in the small, predominantly Māori township of Ruatoki. Also of concern was the use of the Terrorism Suppression Act in a domestic political context, coupled with scepticism about the terrorism charges themselves. In November, the Solicitor-General, who is required to approve any charges under the Terrorism Suppression Act, found that there was insufficient evidence to proceed, and that the requirements of the law were too complex. The Law Commission is now reviewing the Terrorism

73 Dame Margaret Bazley Report of the Commission of Inquiry into Police Conduct (Commission of Inquiry into Police Conduct, Wellington, March 2007) available at www.cipc.govt.nz.

74 Independent Police Conduct Authority Amendment Act 2007.

75 Human Rights Commission Tui Tui Tuituia Race Relations in 2007 (Human Rights Commission, Wellington, March 2008) 75 [Tui Tui Tuituia].

76 For a short summary of the incident, see ibid, 75-76. 
Suppression Act. The outstanding firearms charges are yet to be heard. UN human rights officials have asked the Government to explain the anti-terror raids. ${ }^{77}$

\section{Open Justice}

Openness and transparency in the court system enhances public confidence in the impartial administration of justice. Openness also works to safeguard against judicial bias, corruption, unfairness and incompetence. Most court hearings are generally open to the public and the media, with some limitations in proceedings involving child, youth and family matters. Media coverage may be automatically restricted, for example in certain sexual cases in order to protect the identity of the victim. ${ }^{78}$ Where there are good grounds, there are also sometimes limitations on a case-bycase basis for certain media coverage and publication. In 2006, the Law Commission released a report on access to court records. ${ }^{79}$ The Commission found that access to court records is not as open as court hearings themselves, and made a number of recommendations based on the key principle of open justice, designed to simplify the rules and procedures for access. Although the Government has indicated that a legislative solution may be forthcoming, it has referred the matter to the Justice and Electoral Select Committee for inquiry. ${ }^{80}$ In the meantime, the High Court Rules Committee has prepared its own draft rules for access to court records in civil proceedings in the High Court and in indictable criminal proceedings in both the High Court and District Court. ${ }^{81}$

\section{CULTURE AND LANGUAGE}

\section{A Language}

The 2006 Census showed that there were more than 80 different languages spoken in New Zealand. ${ }^{82}$ English is the most widely used. Māori and New Zealand Sign Language are recognised as official languages. ${ }^{83}$ Other languages commonly used are Pacific languages, Chinese languages, and Hindi.

77 Aotearoa Indigenous Rights Trust "UN investigation into 'terrorism raids'" (7 January 2008) www.Māori party.com (accessed 14 March 2008); "UN orders Govt to explain anti-terror raids" New Zealand Herald (17 January 2008).

78 Criminal Justice Act 1985, s 139.

79 New Zealand Law Commission Access to Court Records Report 93 (New Zealand Law Commission, Wellington, 2006).

80 Hon Rick Barker "Improving access to court records" (9 May 2007).

81 See www.courtsofnz.govt.nz/about/system/rules_committee/consultation (accessed 22 July 2008).

82 "International Covenant on Civil and Political Rights: Fifth Periodic Report of the Government of New Zealand" (21 December 2007) para 419 [ICCPR Fifth Periodic Report].

83 Māori Language Act 1987 and New Zealand Sign Language Act 2006. 
Language is not a separate ground of discrimination in the HRA or BORA. Complaints about language discrimination are however dealt with either in terms of discrimination on the prohibited grounds of "race" or "country of origin." To date, the Government has not considered it necessary to explicitly include language as a prohibited ground of discrimination. ${ }^{84}$ Section 20 of BORA also provides some protection for use of minority languages. ${ }^{85}$ In 2007, under the auspices of the Human Rights Commission, the New Zealand Diversity Action Programme released a Draft Statement on Language Policy. ${ }^{86}$ The Statement is intended to promote discussion on language policy and to provide a framework for greater government and community action to protect and promote language diversity.

Some years ago, there was real concern that the Māori language would not survive. Various claims were taken to the Waitangi Tribunal alleging that the Crown had breached Treaty principles by failing to ensure the survival of the Māori language, te Reo Māori. ${ }^{87}$ As a result of these claims, and related court cases, ${ }^{88}$ there have been a number of developments aimed at protecting and promoting te Reo Māori. A 2006 survey on the health of te Reo Māori showed significant increases in the number of Māori adults who could speak, read, write, and understand te Reo. ${ }^{89}$ Approximately 24 per cent of the Māori population can speak te Reo Māori, of which 10 per cent use their language skills on a regular basis. ${ }^{90}$ The 2003 Māori Language Strategy developed by Te Puni Kokiri (the Ministry of Māori Development) and Te Taura Whiri i te Reo Māori (the Māori Language Commission) is a 25 -year strategy to co-ordinate and prioritise government action in the area of Māori language revitalisation. ${ }^{91}$

84 ICCPR Fifth Periodic Report, above n 82, paras 397-398.

85 Section 20 provides: "A person who belongs to an ethnic, religious, or linguistic minority in New Zealand shall not be denied the right, in community with other members of that minority, to enjoy the culture, to profess and practise the religion, or to use the language, of that minority."

86 Available at www.hrc.co.nz/diversity (accessed 29 February 2008).

87 See Report of the Waitangi Tribunal on the Te Reo Māori Claim (Wai 11, Waitangi Tribunal, 1986); Report of the Waitangi Tribunal on Claims Concerning the Allocation of Radio Frequencies (Wai 26 and 150, Waitangi Tribunal, 1990).

88 See Attorney-General and Secretary of Commerce v New Zealand Māori Council [1991] 2 NZLR 129 (CA); New Zealand Māori Council v Attorney-General [1991] 2 NZLR 147; New Zealand Māori Council v Attorney-General [1992] 2 NZLR 57 (CA) 6; New Zealand Māori Council v Attorney-General [1994] 1 NZLR 513 (PC).

89 Research New Zealand 2006 Survey on the Health of the Mãori Language (Te Puni Kokiri, Wellington, July 2007).

90 ICCPR Fifth Periodic Report, above n 82, para 412.

91 A 2008/2009 review of the Strategy is planned. See Controller and Auditor-General Performance Audit Report: Implementing the Mãori Language Strategy (Office of the Controller and Auditor-General, Wellington, November 2007) 5. 
In the broadcasting sector, a major positive development has been the establishment of the Māori Television Service. ${ }^{92}$ There has also been increased use of Māori words and phrases in other parts of the broadcasting sector. ${ }^{93}$ Te Reo Māori is widely used in early childhood education and schools - both immersion and bilingual. It may be studied as a first or additional language and can be the medium of instruction across all learning areas. It can also be spoken by court witnesses and Members of Parliament in the House. Translation into English is funded by the state.

In 2006, the New Zealand Sign Language Act was passed providing that New Zealand Sign Language (NZSL) is an official language. It permits the use of NZSL in legal proceedings, facilitates competency standards for its interpretation and guides Government departments in its promotion and use. NZSL may also be studied in primary and secondary schools, and can be the medium of instruction.

Various Pacific languages are used in their New Zealand-based communities. The Tokelau, Cook Islands Māori and Niue languages are particularly vulnerable because of low numbers of speakers. As Tokelau is a New Zealand territory, and the Cook Islands and Niue are self-governing states in free association with New Zealand, New Zealand has a particular responsibility to ensure survival of these languages. The Ministry of Pacific Island Affairs is running a "Mind Your Language" project for the Niuean, ${ }^{94}$ Tokelauan and Cook Island communities.

For other Pacific nations, a significant proportion of their populations now live in New Zealand, meaning that language use in New Zealand is important to ensure maintenance and revitalisation of the language. Figures from the 2006 Census show an overall decrease in the percentage of people speaking Pacific languages in New Zealand since the previous Census in 2001. ${ }^{95}$ Various Pacific community groups support first and second language learners through a variety of language programmes. The School Curriculum adopted in 2007 includes languages as a learning area for all students, and a "languages in schooling" strategy is under consideration. The Ministry of Education has recently completed curriculum guidelines for Cook Island Māori, Niuean, Samoan, Tokelauan and Tongan. The Ministry of Pacific Island Affairs intends to explore a Pacific language strategy and further broadcasting opportunities to ensure the sustainability of Pacific languages in New Zealand. ${ }^{96}$

92 Māori Television Service Act 2003.

93 ICCPR Fifth Periodic Report, above n 82, 412.

94 See www.learnniue.com.

95 Tui Tui Tuituia, above n 75, 48.

96 Ministry of Pacific Island Affairs "Briefing for the Incoming Minister" (12 November 2007) para 4. 


\section{B Culture: The Overall Legal Framework}

The legal framework for promoting and protecting culture in New Zealand is a mixed one. It includes section 20 of BORA which provides that persons belonging to ethnic, religious, or linguistic minorities "shall not be denied the right, in community with other members of that minority, to enjoy the culture, to profess and practices the religion, or to use the language, of that minority."

To date, this right has been used infrequently in litigation, and where it has been used, the courts have generally regarded it as a "negative" right requiring government forbearance rather than positive action. ${ }^{97}$ Attempts to use section 20 to support cultural rights or practices have arisen in the context of challenges to state regulation of resources, ${ }^{98}$ disputes between Māori groups, ${ }^{99}$ an application by a defendant to have his criminal proceeding transferred from a court to a marae, ${ }^{100}$ and proceedings concerning disposition of an estate involving a whangai child (a child adopted pursuant to Māori custom). ${ }^{101}$

A second element of the legal framework for culture is the anti-discrimination provisions in the HRA and section 19 of BORA. A number of the prohibited grounds of discrimination may be used to protect aspects of culture including the grounds of religious belief, ethical belief, colour, race, and ethnic or national origins.

The third element of the legal framework for culture is the Treaty of Waitangi 1840 (the Treaty). For Māori, the Treaty has been the primary legal and policy base for promoting and protecting their indigenous rights, including culture. Although the White Paper proposal for the Bill of Rights contained a Treaty clause, it was opposed by some Māori, among other groups, and so BORA itself contains no reference to the Treaty.

Instead, claims based on the Treaty are now put forward in various ways. ${ }^{102}$ First, some use the Treaty to argue that New Zealand's constitutional arrangements are illegitimate and to suggest how the constitution ought to be structured. Secondly, in the political arena, Treaty claims are made as to why one policy rather than another should be adopted; say for example, in the health, education or immigration areas. Thirdly, Treaty claims arise in the courts - most commonly where the relevant

97 Mendelssohn v Attorney-General [1999] 2 NZLR 268, 273 (CA).

98 New Zealand Underwater Assoc Inc v Auckland Regional Council Planning Tribunal A 131/9 (16 December 1991); Kiwifruit Marketing Report (Wai 449, Waitangi Tribunal, 1995).

99 Ngati Apa Ki Te Waipounamu Trust v R [2000] 2 NZLR 659 (CA).

100 Police v Taurua [2002] DCR 306.

101 Keelan v Peach [2003] NZFLR 727 (CA).

102 See Rishworth et al, above n 23, 411-412. 
legislation contains a "Treaty clause." Since the late 1980s, "Treaty clauses" have been included in certain legislation - particularly that concerning land and natural resources. For example, section 9 of the State-Owned Enterprises Act 1986 provides that "nothing in this Act shall permit the Crown to act in a manner that is inconsistent with the principles of the Treaty of Waitangi." In the late 1980s and 1990s, there were a number of cases where Māori argued, successfully in a number of cases, that the Crown had breached Treaty principles by certain actions or omissions. ${ }^{103}$ In recent years, there have been various calls to remove "Treaty clauses" from legislation. The most recent attempt was the Principles of the Treaty of Waitangi Deletion Bill 2006. This Private Member's Bill was referred to the Justice and Electoral Select Committee, which concluded that its passage would have a negative impact on relationships between Māori and the Crown. Parliament rejected the Bill in November 2007.

Since 1985, the Waitangi Tribunal, established under the Treaty of Waitangi Act 1975, has been able to hear historical claims dating back to 6 February 1840 alleging Crown breach of Treaty principles. In 2006, the Act was amended to require that historical claims must be filed by 1 September 2008. ${ }^{104}$ The Waitangi Tribunal makes findings as to whether the Crown has breached Treaty principles, and generally makes recommendations as to appropriate redress. The Crown takes Tribunal reports into account in negotiating settlements of both historical land and resource claims, and contemporary claims. Historic land settlements usually contain an apology from the Crown, financial redress, return of land and other resources, and provisions for ongoing relationship between the Māori group and the Crown. Many of these cover cultural issues. Some specific examples of provision for culture in Treaty settlements are the use of joint English/Māori place names and acknowledgement of traditional food gathering sources.

A final element of the legal framework, which may be used to protect and promote aspects of indigenous culture, is the common law doctrine of aboriginal title. ${ }^{105}$ The doctrine of aboriginal title has been used to protect customary Māori fishing rights, ${ }^{106}$ and was the basis for Māori claims in the foreshore and seabed case. ${ }^{107}$

103 See for example New Zealand Mäori Council v Attorney-General [1987] 1 NZLR 641 (CA); New Zealand Māori Council v Attorney-General [1989] 2 NZLR 142 (CA); Tainui Trust Board v Attorney-General [1989] 2 NZLR 513 (CA); Te Runanganui o Wharekauri Rekohu v Attorney-General [1993] 2 NZLR 301 (CA); Te Runanganui o Te Ika Whenua v Attorney-General [1994] 2 NZLR 20 (CA).

104 Treaty of Waitangi Act 1975 s 6AA.

105 For further discussion, see Joseph, above n 32, para 3.11.

106 Te Weehi v Regional Fisheries Officer [1986] 1 NZLR 680 (HC).

107 Attorney-General v Ngati Apa [2003] 3 NZLR 643 (CA). 


\section{Current Issues of Concern}

\section{Declaration on the Rights of Indigenous Peoples}

The UN General Assembly adopted the Declaration on the Rights of Indigenous Peoples in September 2007. ${ }^{108}$ The Declaration is aspirational and does not contain binding legal obligations. Although New Zealand was actively involved in negotiations on the Declaration, it was one of only four countries that voted against the final text, along with Australia, Canada and the United States. Four provisions of the Declaration (articles 19, 26, 28 and 32) were said to be incompatible with New Zealand's constitutional and legal arrangements, the Treaty of Waitangi, and the need to govern for the good of all citizens. ${ }^{109}$

\section{Continued dialogue on foreshore and seabed}

In its 2007 concluding comments on New Zealand's $15^{\text {th }}-17^{\text {th }}$ periodic report to the CERD Committee, ${ }^{110}$ the Committee recommended further engagement between Māori and the Crown on the foreshore/seabed issue. ${ }^{111}$ However, dialogue on the broader constitutional issues stemming from that debate seems unlikely, although the new Government has indicated that it may review the Foreshore and Seabed Act 2004. In the meantime, nine applications have been made to the Māori Land Court for customary rights orders under the Foreshore and Seabed Act 2004. Four of these have been publicly notified, three are in the preliminary stages and two have been dismissed. ${ }^{112}$ The First Heads of Agreement under the Foreshore and Seabed Act was signed between Ngati Porou and the Crown in February 2008. ${ }^{113}$

\section{Burial disputes}

In the past year, there have been three "body-snatching" cases involving disputes between family members over burial of loved ones. In all cases, one reason given for taking the body has been traditional Māori custom, although the extent to which cultural difference has been an element

108 Declaration on the Rights of Indigenous Peoples (13 September 2007) UNGA Res A/RES/61/295.

109 "Explanation of Vote by HR Rosemary Banks, New Zealand Permanent Representative to the UN" (13 September 2007) www.mfat.govt.nz/MediaandPublications/ (accessed 29 February 2008).

$110 \mathrm{CERD} / \mathrm{C} / \mathrm{NZL} / 17(2006)$

$111 \mathrm{CERD} / \mathrm{C} / \mathrm{NZL} / \mathrm{CO} / 17$ (2007) para 23.

112 Tui Tui Tuituia, above n 75, 30.

113 Michael Cullen "Foreshore and Seabed Heads of Agreement with Ngati Porou" Press Release (5 February 2008). 
in these disputes is debated. In response to the most recent incident, there have been a number of calls for a legal solution. ${ }^{114}$

\section{Tensions Between Culture and Other Rights}

1 The right to culture and the right to be free from gender discrimination

The right to culture, or Māori culture specifically, and its relationship to the right to be free from discrimination on the grounds of gender has received some attention in recent years. ${ }^{115}$ In 2005 , a female Pakeha probation officer claimed that the Department of Corrections discriminated against her because of the role that women were expected to play in a poroporoaki (farewell) for male offenders who had completed a violence prevention programme. Her concern in particular was that women were not permitted to speak or to sit in the front row of the ceremony. The former probation officer took her claim to the HRRT who agreed that there was detrimental treatment because of her sex, but declined to award any monetary damages. ${ }^{116}$ The Department of Corrections has released new guidelines aimed at protecting traditional values while ensuring that Corrections has a framework that permits participation by all staff. Less formal whakatau ceremonies are now used which feature the same roles for men and women, and permit the use of languages other than Māori. ${ }^{117}$

More recently, in its comments on New Zealand's sixth periodic report under CEDAW, the CEDAW Committee noted its concern that violence against women within families and illegal practices relating to marriage on the basis of culture and religion take place within immigrant communities and may not be adequately addressed because of the dependency and isolation of the women. The Committee recommended that New Zealand undertake outreach measures to women victims in immigrant communities. ${ }^{118}$

\section{The right to religion/culture and the right to a fair trial}

A 2005 case raised the issue of potential conflict between the rights of two witnesses to practise their religion (and implicitly culture) on the one hand, and the right of the defendant to a fair trial on

114 James Ihaka and Elizabeth Binning "Body snatched from hearse" New Zealand Herald (6 March 2008); "Coroner proposes 'body snatching' law change" New Zealand Herald (10 March 2008).

115 For earlier academic discussion, see Claire Charters "Universalism and Cultural Relativism in the Context of Indigenous Women's Rights" in P Morris and H Greatrex (eds) Human Rights Research Victoria University of Wellington (Milne Printers Limited, Wellington, 2003) 19. See also New Zealand Law Commission Converging Currents: Custom and Human Rights in the Pacific Study Paper 17 (New Zealand Law Commission, Wellington, 2006) ch 7.

116 Bullock v Department of Corrections [2008] NZHRRT 4 (19 March 2008).

117 Department of Corrections "Policy for Māori Cultural Practices Announced" (18 January 2006).

$118 \mathrm{CEDAW} / \mathrm{C} / \mathrm{NZL} / \mathrm{CO} / 6$ (2007) paras 26-27. 
the other. In Police v Razamjoo, ${ }^{119}$ police wanted to call two female witnesses who wished to give evidence wearing their burqas (the most concealing of the Muslim veil, covering the entire face and body). The concern was that if the witnesses wore their burqa, this might negatively impact on the ability of the defendant's lawyer to effectively cross-examine the witnesses. The main issue was whether the witnesses were able to give evidence wearing their burqa, and if so, whether this would be a breach of the defendant's right to a fair trial. The corollary to this was if the witnesses were not permitted to wear their burqa while giving evidence, whether this would be a breach of their rights to religion guaranteed under sections 13 and 20 of BORA. The court held that the witnesses were to give their evidence without wearing a burqa but from behind a screen and out of public view - only the judge, counsel and female court staff were able to observe the witnesses' faces. Significantly, the court noted that "rights of manifestation" such as those in section 20 must necessarily be subject to constraints of many types including public health, hygiene, environmental health, and workplace safety. ${ }^{120}$

\section{F Affirmative Uses of Culture}

No attempt is made in this section to comprehensively capture all affirmative uses of culture. ${ }^{121}$ Instead, four examples of positive uses of culture are given.

\section{Converging Currents: Custom and Human Rights in the Pacific}

In 2006, the Law Commission released a Study Paper looking at the relationship between custom and human rights in the Pacific, including New Zealand. ${ }^{122}$ The study started with two objectives of Pacific leaders - to maintain local values and customs and to implement universal human rights, and examined the perceived conflicts between these two objectives. The key thesis of the study was that custom and human rights could be harmonised by looking at the shared underlying values of both.

\section{Culture in child welfare proceedings}

The Care of Children Act 2004 provides that one of the principles to be considered in determining a child's welfare and best interests is that a child's identity including culture, language, and religious denomination and practice should be preserved and strengthened. ${ }^{123}$ A number of

119 Police v Razamjoo [2005] DCR 408.

120 For further commentary, see Human Rights Commission "Muslim Women, Dress Codes and Human Rights: an introduction to some of the issues" (Human Rights Commission, Wellington, December 2005).

121 For further specific instances of affirmative uses of culture, as well as issues of concern, see Tui Tui Tuituia, above $n 75$.

122 See New Zealand Law Commission, above n 115.

123 Care of Children Act 2004, s 5(f). 
statutes also make provision for "cultural reports" to be considered in determining custody, access and guardianship arrangements. ${ }^{124}$

\section{School Curriculum 2007}

The Human Rights Commission highlighted the new School Curriculum as the most significant positive development in race relations in 2007. ${ }^{125}$ Three of the eight core principles underpinning the new curriculum are relevant to both race relations and culture, namely the Treaty of Waitangi, cultural diversity and inclusion. Throughout the Curriculum, students are to be encouraged to value diversity, as found in different cultures, languages and heritages.

4 UNESCO Convention for the Protection and Promotion of the Diversity of Cultural Expressions

In October 2007, New Zealand acceded to the UNESCO Convention for the Protection and Promotion of the Diversity of Cultural Expressions. ${ }^{126}$ This Convention aims to establish an international environment in which the diversity of cultural expression is affirmed and encouraged. A key objective is to take into account cultural diversity when developing other policies. The preamble emphasises:

The need to incorporate culture as a strategic element in national and international development policies,

as well as in international development cooperation, taking into account also the United Nations

Millennium Declaration (2000) with its special emphasis on poverty eradication.

The Convention recognises the significance of cultural activities, goods and services as vehicles of identity, values and meaning. The text of the Convention is however essentially aspirational, with few binding legal obligations.

\section{EDUCATION}

Education is regarded as both a human right in itself and an indispensable means of facilitating the enjoyment of the full range of human rights and respect for the rights of others. ${ }^{127}$ In New Zealand, the right to education is recognised in statute and its prime importance has been recognised

124 See for example Children Young Persons and Their Families Act 1989, s 189; Care of Children Act 2004, s 133(3).

125 Tui Tui Tuituia, above n 75, 5-6.

126 United Nations Educational, Scientific and Cultural Organization Convention for the Protection and Promotion of the Diversity of Cultural Expressions (20 October 2005).

127 United Nations Economic and Social Council Annual Report of the Special Rapporteur on the Right to Education 2005 (17 December 2004) E/CN.4/2005/50 para 6. See Advisory Council of Jurists Asia Pacific Forum of National Human Rights Institutions [APF] Reference on the Right to Education Final Report (2007) http://asiapacificforum.net (accessed 7 April 2008). 
by the courts. ${ }^{128}$ New Zealand has also ratified a number of international treaties which affirm the right of access to free education. ${ }^{129}$ It is clear, however, that although the right to education is generally secured, there are some areas of concern.

\section{A New Zealand Education System}

The right finds its domestic expression in section 3 of the Education Act 1989 which provides that everyone has the right to free primary and secondary education from the age of five until the age of 19. Every person who is not a foreign student is required to be enrolled in school between the ages of six and 16. ${ }^{130}$ Parents who fail or refuse to ensure that a person in that age group is enrolled at a registered school and attends regularly, face summary conviction and financial penalties. ${ }^{131}$

\section{Participation}

Freedom from discrimination in education is guaranteed by section 19(1) of BORA which provides that "[e]veryone has the right to freedom from discrimination" and refers to the prohibited grounds of discrimination in the HRA. ${ }^{132}$ Primary and secondary school students have the opportunity to be enrolled in a variety of different types of schools: single sex schools, private schools, integrated religious schools, Kura Kaupapa Māori schools (immersion schools) and the correspondence school (caters for students unable to attend school due to geographical inaccessibility, illness, disability or exclusion). ${ }^{133}$ Zoning ensures that each child has access to state schooling in their area, but students may be selected from outside the home zone, according to certain priorities. ${ }^{134}$

128 Bovaird and Board of Trustees of Lynfield College v J [2008] NZAR 667, para 23 (CA); Attorney-General v Daniels [2003] 2 NZLR 742, para 69 (CA).

129 ICESCR, Arts 13 and 14; International Convention on the Elimination of All Forms of Racial Discrimination (7 March1966) 660 UNTS 195 [CERD] (Arts 5(e) and 7); CEDAW, Art 10; Convention on the Rights of the Child (20 November 1989) 1577 UNTS 3 [CRC] (Art 23); Convention Against Discrimination in Education (14 December 1960) 429 UNTS 93; and Convention on the Rights of Persons with Disabilities (13 December 2006), Art 24.

130 Education Act 1989, ss 20 and 25.

131 Ibid, ss 24, 29 and 30

132 Section 19 is subject to the "reasonable limitation" provision in BORA s 5. As the school board performs a "public function, power or duty conferred or imposed on that ... body by law", (BORA s 3) BORA applies to their actions: see Rishworth "Religious Issues in State, Integrated and Private Schools" in New Zealand Law Society Seminar Education Law (2006) 98.

133 Education Act 1989, ss 28, 146A, 155. Exemptions can also be granted for home schooling in s 21.

134 Ibid, ss $11 \mathrm{C}, 11 \mathrm{~F}$ and $11 \mathrm{O}$ 
Participation rates in New Zealand early childhood, primary and secondary education are relatively high compared to other OECD countries. ${ }^{135}$ However, the difference in participation and achievement rates between low and high decile schools and among some ethnic groups is marked. ${ }^{136}$ Although New Zealand children rank relatively highly in international education achievement standards, there is also still a significant gap between the highest and lowest achieving students. ${ }^{137}$ This disparity reflects the disadvantages of some social, cultural and economic groups.

As tertiary institutions (universities, polytechnics, colleges of education and wananga ${ }^{138}$ ) have autonomy under the Education Act, enrolment is generally a matter for the tertiary institution. ${ }^{139}$ In recent years there have been improvements in participation at tertiary level, especially in terms of Māori engagement. ${ }^{140}$ However, an alteration in the funding for tertiary institutions so that tertiary institutions are funded on the basis of three-year investment plans rather than allocated on the basis of enrolments, has prompted some universities to adopt restrictions on their future intakes of undergraduate students. ${ }^{141}$ There has been criticism that these limits will create universities of the elite from which some groups would be excluded.

The extent to which education in New Zealand is truly accessible can also be measured by affordability and government funding models. Early childhood education is subsidised by the Government and from 1 July 2007, the Government provided up to twenty hours a week of free early childhood education to children aged three to four years. ${ }^{142}$ Operational funding for primary and secondary schools is allocated according to the decile system. ${ }^{143}$ Decile calculations are based on household income, occupation, household crowding, educational qualifications of parents, and

135 Statistics New Zealand New Zealand in the OECD (2005) www.stats.govt.nz (accessed 25 February 2008) 18. New Zealand ranked $9^{\text {th }}$ out of 30 OECD countries for four year olds involved in early childhood education and ranked $12^{\text {th }}$ in terms of achievement of secondary or tertiary education qualifications.

136 Education Counts State of Education in New Zealand 2007 www.educationcounts.govt.nz (accessed 18 February 2008) 41 and 50 [State of Education].

137 Ibid, 27.

138 Wananga deliver tertiary educational programmes within a Māori environment.

139 Education Act 1989, ss 160 and 161. Positive discrimination (preferential entry) is permitted for tertiary institutions under the Education Act 1989, s 224.

140 State of Education, above n 136, 61 and 62.

141 Education (Tertiary Reform) Amendment Bill no. 114-1, 1-2; AUS Tertiary Update Vol 10(46) 13 December 2007 www.aus.ac.nz (accessed 18 February 2008). Education Act 1989 s 224(6) (limits on student numbers can be imposed on students under 20).

142 State of Education, above n 136, 16.

143 Decile ten schools are those in the most affluent areas, and decile one schools are in the lowest socioeconomic zones. 
reliance on welfare. ${ }^{144}$ In this way extra funding can be provided for lower socio-economic communities, te Reo Māori programmes, special education needs and rural schools.

Although state schools are intended to be fully funded to meet the requirements of the National Education Guidelines, many schools levy voluntary "donations" to provide what many argue are essential educational services. Low socio-economic students are identified as being disadvantaged in this manner. ${ }^{145}$

The Government and students share the costs of tertiary education. Tertiary students pay tuition fees equivalent to four weeks gross earnings at the average weekly wage as at $2006 .{ }^{146}$ Government loans are, however, available to nearly all New Zealand students through the Student Loan Scheme. ${ }^{147}$ Since 2005, student loans have been interest-free for borrowers who remain in New Zealand and loan repayment is income-contingent. ${ }^{148}$ Student groups have however expressed concerns that the potential for significant debt, albeit without interest, could still inhibit access to higher education. ${ }^{149}$ Student allowances are available for full-time students who meet targeting criteria to help meet living costs. ${ }^{150}$

\section{Ensuring compliance with minimum standards}

Minimum standards in early childhood education are established through a licensing system that sets standards in relation to curriculum, teaching, administration, health and safety. Regarding the control of primary and secondary schools, each school community elects a Board of Trustees (BOT), which includes staff, student and parent representatives to manage the school. ${ }^{151}$ The National Education and Administration Guidelines require schools to follow the National Curriculum and BOTs are required to report on compliance with school charters, as well as three -

144 Ministry for Education "Frequently Asked Questions About Deciles" www.minedu.govt.nz (accessed 18 February 2008).

145 Human Rights Today, above n 15, 12-13.

146 State of Education, above n 136, 64. The Government sets limits on fees to prevent sharp fee rises.

147 Students can borrow tuition fees and course-related costs. Full-time students can borrow living costs.

148 Prior to this there was criticism that the student loan scheme discriminated against women and those with disabilities. Since these groups on average earned less and took longer to pay off their student loans, they incurred more interest. Since the change to interest-free loans this criticism has essentially dissipated.

149 The nominal face value of loan balances reached $\$ 9,412.7$ million as at 30 June 2007 and a total of 499,259 people were recorded as having a student loan. Ministry of Education Student Loan Scheme Annual Report to 30 June 2007 www.educationcounts.govt.nz (accessed 15 July 2008).

150 Education Act 1989, s 303.

151 Ibid, ss 75 and 94. 
five year strategic plans. ${ }^{152}$ The Education Review Office (ERO) regularly reviews schools for compliance with the Guidelines and the Ministry of Education has powers to intervene in the operations of schools. ${ }^{153}$ Further checks are provided by the New Zealand Qualifications Authority, which can issue compliance notices to secondary schools, and the Office of the Ombudsman, which reviews decisions of educational institutions.

Primary and secondary school teachers must be fully qualified and registered with the New Zealand Teachers Council. ${ }^{154}$ There are shortages in primary and secondary teacher numbers, especially in the Auckland region. ${ }^{155}$ There is also a need for more teachers who are Māori and from the Pacific, especially in early childhood education. ${ }^{156}$ Incentive schemes are used to attract adequately qualified and trained teachers especially in shortage subjects, such as mathematics and physical sciences.

\section{Disability and special needs education}

New Zealand has statutory and international obligations to recognise the equal right of students with disabilities and special needs to participate in education. ${ }^{157}$ However, the Human Rights Commission has continued to receive complaints about the failure of mainstream schools to meet the needs of disabled and special needs students and the inequitable distribution of resources among disability groups.

In order to cater for students' special needs and disabilities, all schools receive a grant called the Special Education Grant (SEG) and can access resource teachers. ${ }^{158}$ However an ERO report in June 2005 identified a wide disparity in the level of effectiveness in using SEGs to improve special needs students' outcomes. ${ }^{159}$ In April 2001 the Government launched the New Zealand Disability Strategy designed to ensure equitable access to education and resources for students with special

152 National Curriculum Statements describe what students are taught during primary and secondary schooling; Education Act 1989, ss 60A and 87.

153 Education Act 1989, ss 78A and 78I.

154 Aim for all early childhood teachers to be qualified by 2012: State of Education, above n 136, 21.

155 Primary teachers with at least three years experience are now on Immigration New Zealand's Immediate Skill Shortage List for work permits or residency: see Teach NZ www.teachnz.govt.nz (accessed 25 February 2008).

156 In state schools 22 per cent of students are Māori compared with 10 per cent of teachers who are Māori: www.teachnz.govt.nz (accessed 10 March 2008).

157 Education Act 1989 ss 8 and 9. See also the CRC Art 23; Declaration on the Rights of Disabled Persons; and Convention against Discrimination in Education.

158 Ministry of Education "What is special education?" www.minedu.govt.nz (accessed 25 February 2008).

159 Education Review Office An Evaluation of the Special Education Grant June 2005 http://ero.govt.nz (accessed 25 February 2008). 
needs, and improve the responsiveness and accountability of schools. ${ }^{160}$ Parents can also choose to send their child to a special school that is specifically equipped to support children with special educational needs, if the Secretary of Education agrees. ${ }^{161}$

The issue of education rights for special needs students has been the subject of court action. ${ }^{162}$ It has been held by the High Court that there is no general duty to make decisions in the interests of enhancing the educational prospects of special needs students or to provide sufficient funding for students' special needs (although a duty to a specific student has not been ruled out). ${ }^{163}$ A duty may exist, however, to use reasonable care and skill in assessing the student's needs category and allocating the student to a mainstream or special school. ${ }^{164}$

\section{Māori and Pacific Students}

Education achievement indicators highlight concerns that a disproportionate percentage of Māori and Pacific students are failing within current education structures. Successful participation rates for Māori are disproportionately low; ${ }^{165}$ Māori have higher truancy, ${ }^{166}$ lower achievement levels, ${ }^{167}$ and higher stand-down, suspension, exclusion and expulsion rates than students of other ethnicities. ${ }^{168}$

The Ministry of Education has attempted to ameliorate this by providing specific services and programmes for Māori such as Kura Kaupapa Māori, and bilingual units in schools that validate Māori structures and learning styles. ${ }^{169}$ Each school's charter must have the aim of developing

160 See Office for Disability Issues www.odi.govt.nz/nzds and Ministry of Education New Zealand Disability Strategy Implementation 2007 Work Plan 2007-2008 and Report on Progress 2006-2007 www.odi.govt.nz/nzds (both accessed 10 March 2008).

161 Education Act 1989, s 9.

162 See, for example, Attorney-General v Daniels, above n 59.

163 Anderson by his litigation guardian Eric Anderson v Attorney-General HC AK (6 June 2007) CIV 2004404-002511 para 45. Attorney-General v Daniels, however, stated that there is no free-standing general right, held and enforceable by each individual student under ss 3 and 8 - see para 83 .

164 Anderson v Attorney-General, above n 163, paras 72-73.

165 State of Education, above n 136, 50.

166 Education Counts Attendance, Absence and Truancy in New Zealand Schools in 2006 www.educationcounts.govt.nz (accessed 25 February 2008).

167 State of Education, above n 136, 47.

168 Ibid, 34.

169 Education Counts Māori Medium Education as at 1 July 2007 www.educationcounts.govt.nz (accessed 10 March 2008). United Nations Economic and Social Council Annual Report of the Special Rapporteur on the Right to Education 2005 (17 December 2004) E/CN.4/2005/50 para 96 supports the rights of indigenous communities to develop their own educational proposals. 
policies and practices that recognise the unique position of Māori culture. ${ }^{170}$ From 2006, Māori language programming resources will be extended to all students learning Māori, not just Māori students. ${ }^{171}$

Following the implementation of the 2001 Pasifika Education Plan, the Government launched a new action plan in June 2006 aimed at improving educational achievement and participation among Pacific students. ${ }^{172}$ The plan commits additional funding over four years to support literacy, focus on community support and provide teaching resources and development.

\section{Education for children unlawfully present in New Zealand}

The Committee on the Rights of the Child has criticised New Zealand for differential treatment of non-citizen children in terms of access to education. ${ }^{173}$ The Immigration Bill currently before Parliament aims to remedy this by allowing non-citizen children to attend school while present in New Zealand. ${ }^{174}$ A temporary policy initiative to the same effect has been implemented. ${ }^{175}$

\section{Gender parity}

The focus of gender parity and equality issues has recently shifted to the achievement disparity of boys. In the 1990s, girls' achievement matched or had even overtaken boys in subjects where they had previously been under-achieving. ${ }^{176}$ The Ministry of Education's Boys' Educational Achievement Reference Group, established in 2004, has identified problems with literacy standards for boys, ${ }^{177}$ disengagement with academic learning, and an increase in negative behaviour. ${ }^{178}$

170 Education Act 1989, s 61.

171 Ministry of Education Māori Language Programme Resourcing Changes www.moe.govt.nz (accessed 18 February 2008).

172 Ministry of Education Pasifika Education Plan 2006-2010 www.minedu.govt.nz (accessed 15 February 2008)

173 CRC Committee "Consideration of Reports Submitted by States Parties under Article 44 of the Convention Second Periodic Report of States Parties: New Zealand" (12 March 2003) CRC/C/93/Add.4 (2001) para 24(i). See also CERD/C/NZL/CO/17 (2007) para 23. New Zealand proposes to withdraw this reservation following enactment of the Immigration Bill currently before Parliament (see Appendix 2: Progress on UNCROC Work Programme www.myd.govt.nz (accessed 18 January 2008)).

174 United Nations Committee on the Rights of the Child Five-year Work Programme Update (Summary Document) www.myd.govt.nz (accessed 10 March 2008).

175 New Zealand Immigration Service Policy Manual L8.10 www.immigration.govt.nz (effective from 25 July 2007) (accessed 10 March 2008).

176 State of Education, above n 136, 28 and 29.

177 Ibid, 27. New Zealand has one of the largest literacy gender gaps in the OECD. 


\section{$7 \quad$ Religious or cultural beliefs}

New Zealand's compulsory education system is basically secular ${ }^{179}$ and controversies rarely lead to litigation. ${ }^{180}$ Despite the lack of precedent, however, religious controversies in schools are occurring at an increasing rate. ${ }^{181}$ Voluntary instructors outside of teaching hours may give religious instruction at state schools, ${ }^{182}$ and state-integrated religious schools are permitted to retain their special character (conditional on the terms of their integration agreement). ${ }^{183}$ Students aged over 16 years (or their parents if they are under that age), are permitted to opt out of a particular class due to religious or cultural grounds. ${ }^{184}$

\section{B Disciplinary Issues}

Corporal punishment was banned from New Zealand schools in 1990 and now detention is the most common form of discipline. ${ }^{185}$ Other forms of behaviour management include stand-down, suspension, exclusion or expulsion. ${ }^{186}$ Although recent reports suggest that the proportion of students being stood down and suspended are falling, males and Māori students in particular continue to be over-represented. ${ }^{187}$ Students from schools in the lowest two deciles are between two

178 Ministry of Education Explaining and Addressing Gender Differences in the New Zealand Compulsory School Sector (2000) www.educationcounts.govt.nz (accessed 18 February 2008). State of Education, above n $136,32-34$.

179 Education Act 1964, s 77.

180 Rishworth, above n 132, 88.

181 Ibid, 87 and 90.

182 Education Act 1964, s 78.

183 Ibid, s 78. No similar provision for secondary schools exists. It has been suggested that such a power could be inferred from ss $75-76$ of the Education Act 1989 (general power of governance). Private Schools Conditional Integration Act 1975, s 32.

184 Education Act 1989, s 25A. There is some risk that the ability of schools to provide voluntary religious education might be seen as discriminatory as it privileges the rights of religious students over students who are non-religious. Since religious instruction is authorised by statute, however, even if the religious instruction is held to be inconsistent with a students' freedom of religion (or freedom from religion), $\mathrm{s} 78$ trumps the right to religious freedom under the BORA due to s 4 of the BORA which preserves the supremacy of other statutes over the BORA where a consistent interpretation is not possible. See Rishworth, above $\mathrm{n} 132,105$

185 Education Act 1989, s 139A.

186 Ibid, s 14(2). There are time limits on stand-downs but no limit for suspensions. Exclusion is formal removal of a student under 16. Expulsion is formal removal of a student aged over 16. Ministry of Education Guidelines for Principals and Board of Trustees on Stand-downs, Suspension, Exclusions and Expulsions (2007) www.minedu.govt.nz (accessed 25 February 2008).

187 State of Education, above n 136, 33. 
and five times more likely to be stood down, suspended, excluded or expelled as those from the highest two deciles. ${ }^{188}$

Due to rising rates, truancy is an increasingly important disciplinary issue. ${ }^{189}$ The Student Engagement Initiative (SEI) was established in 2003 in 63 schools with the highest proportion of suspensions, truancy and early leaving exemption to remedy these disciplinary issues. This programme has demonstrated success in addressing the high proportion of truancy and in particular, Māori suspensions in secondary schools via the Suspension Reduction Initiative. ${ }^{190}$

In terms of the judicial review of school disciplinary practices, relatively few cases have been litigated. ${ }^{191}$ It is clear, however, that in deciding whether to engage in any disciplinary action, the BOT and principals must take into account all circumstances and not rely on the automatic application of a disciplinary policy. ${ }^{192}$ The need to accord students natural justice rights in disciplinary proceedings is now confirmed. ${ }^{193}$ Private schools are also likely to be subject to judicial review due to the wide approach to judicial review followed in New Zealand. ${ }^{194}$

\section{HEALTH}

\section{A Background}

The right to health has long been recognised as being necessary for the dignity of the person and it is expressly referred to in the earliest treaties guaranteeing international human rights. ${ }^{195} \mathrm{By}$ recognising a right to health, states are agreeing to protect the health of citizens and provide the services, policies and budgetary means to promote good health and to ensure the elimination of

188 Ibid, 32-33.

189 Education Counts Attendance, Absence and Truancy in New Zealand Schools in 2006.

190 Suspension Reduction Initiative www.tki.org.nz (accessed 18 February 2008). State of Education, above n $136,34$.

191 Rich v Christchurch Girls' High School Board of Governors [1974] 1 NZLR 1 (CA); Edwards v Onehunga High School Board [1974] 2 NZLR 238 (CA); Maddever v Umawera High School Board of Trustees [1993] 2 NZLR 478 (HC); $M$ and $R v S$ and Board of Trustees of Palmerston North Boys' High School [2003] NZAR 705 (HC); D v M and Board of Trustees of Auckland Grammar School [2003] NZAR 726 (HC); and Bovaird $v J$, above n 128.

$192 M$ and $R v S$ and Palmerston North Boys' High School, above n 191, 737; D v M and Board of Trustees of Auckland Grammar School, above n 191, 716-717.

$193 D v M$ and Board of Trustees, above $\mathrm{n} 191$ and Bovaird v J, above n 128. Education Act 1989, s 13.

194 Caldwell "Judicial Review of School Discipline" (2006) 22(2) NZULR 240, 252 - 253.

195 See the Preamble to the Constitution of the World Health Organisation (1946) which affirms health is a fundamental right and "[g]overnments have a responsibility for the health of their peoples which can be fulfilled only by the provision of adequate health and social measures." See also Art 25 of the Universal Declaration on Human Rights (10 December 1948) UN Doc GA/Res/217A (III) [UDHR]; Art 12 ICESCR. 
health based discrimination. While the precise extent of states' obligations in relation to the right to health can be difficult to determine, ${ }^{196}$ the core content of states' obligations can be defined and states' performance in relation to health guarantees may be measured using a system of indicators and benchmarks. In this report, the right to health has been divided into three categories: the right to healthcare services, the right to underlying pre-conditions for good health and the right to be free from discrimination on the basis of health status.

While New Zealand's constitution does not recognise an express right to health, New Zealand has ratified ICESCR, indicating the Government's agreement to comply with international standards in this regard. ${ }^{197}$ The legislature has enacted a wide range of domestic public health legislation regarding the provision of adequate health services, the creation of suitable preconditions to promote good health and in support of the right to be free from discrimination on the basis of health status. 198

\section{B The Right to Healthcare Services}

\section{Quality of healthcare services}

Although New Zealand does not spend as much per capita on health as many other developed countries, health spending has recently increased, resulting in improvements in health status for individuals. ${ }^{199}$ The Government has endorsed a number of independent public inquiries ${ }^{200}$ and has introduced a range of health strategies which have led to improvements in the provision of public health services.

In particular, "The New Zealand Health Strategy" introduced in 2000 provides a framework for improved health and health care services, and aims to reduce inequalities in health status. In addition, in 1996, a Code to ensure the quality of health services in New Zealand and to protect health consumers' rights was adopted. ${ }^{201}$ The Code is monitored and enforced by the Office of the

196 For further information on the scope of the right to health, see Brigit Toebes "The Right to Health" in A Eide, C Krause and A Rosa (eds) Economic, Social and Cultural Rights: A Textbook (2 ed, Martinus Nijhoff Publishers, Dordrecht, 2001) 169.

197 New Zealand ratified ICESCR in 1978, although the Government continues to express the view that the covenant is not necessarily justiciable. See United Nations Economic and Social Council Second Periodic Report on the Implementation of the International Covenant on Economic, Social and Cultural Rights: Addendum New Zealand (30 September 2001) E/1990/6/Add.33 para 50.

198 For example, the New Zealand Public Health and Disability Act 2000; the Health (Drinking Water) Amendment Act 2007 and the HRA, s 21(1)(h).

199 See Human Rights Today, above n 15, 5.

200 For example the 1987 Cartwright Inquiry into the treatment of women with cervical cancer investigated the issue of patients' rights and led to the establishment of a National Cervical Screening Programme.

201 The Code of Health and Disability Services Consumers' Rights under the Health and Disability Commissioner Act 1994 applies to all health and disability services in New Zealand. 
Health and Disability Commissioner, whose mandate includes investigating and reporting on individual complaints. In the event the Commissioner recommends further action, this may result in disciplinary proceedings before the Health Practitioners Disciplinary Tribunal or proceedings at the HRRT. In 1999, District Health Boards (DHBs) were established with responsibility for providing health services. This model was introduced to devolve power, improve transparency and encourage greater local engagement in health services management. DHBs are required to set out objectives in an annual plan, which is reviewed quarterly against each board's performance.

Also relevant in the health context is the Accident Compensation Corporation (ACC) scheme which provides no-fault personal injury insurance cover for all New Zealand citizens, residents and temporary visitors to New Zealand. In return, individuals do not have the right to sue for personal injury, other than for exemplary damages. The ACC scheme has been in existence for over 30 years and currently operates under the Injury Prevention, Rehabilitation, and Compensation Act 2001.

While health services in New Zealand may generally be viewed favourably by international standards, the Health and Disability Commissioner has recently described the standard of safety in New Zealand hospitals as unacceptable with services that are "slow, patchy and uncoordinated."202 The Quality Improvement Committee has also recently released an unprecedented report indicating a high number of clinical incidents in New Zealand hospitals, with some resulting in preventable deaths. ${ }^{203}$ In addition, a call has been made for the Ministry of Health to introduce national treatment guidelines, following the fatal misdiagnosis of a patient by paramedics, to prevent similar unnecessary deaths arising out of the provision of ambulance services in the future. ${ }^{204}$

\section{Access to health care services}

Access to health care services is also subject to ongoing concern in New Zealand. In particular, the inadequate provision of timely surgical treatment and the availability of suitable medicines for life threatening illnesses such as heart disease and cancer have resulted in widespread criticism and

202 The Health and Disability Commissioner made these statements during the presentation of his Annual Report to the parliamentary health select committee: "Health watchdog advocates big shake-up of hospital system" New Zealand Herald (14 February 2008).

203 The report showed that in the 2006-2007 period there were 40 preventable deaths and 182 patients involved in actual or potentially preventable clinical incidents in hospitals throughout New Zealand. See Quality Improvement Committee Report Commentary on Sentinel and Serious Events Reported by District Health Boards 2006/07 20 February 2008) www.qic.health.govt.nz (accessed 21 February 2008). The Minister of Health has welcomed the report, and has expressed his support for measures which will encourage openness and improve the provision of health services in New Zealand. See Rebecca Palmer and Lane Nichols "40 preventable deaths in New Zealand hospitals" The Dominion Post www.stuff.co.nz/dominionpost/ 4407368a6000.html (accessed 21 February 2008).

204 See Nathan Beaumont "Call for national paramedic standards" The Dominion Post www.stuff.co.nz/ 4411027a10.html (accessed 22 February 2008). 
questions regarding the allocation of resources to ensure adequate access to health care. ${ }^{205}$ The Government has recently faced questions over the death of patients waiting for cardiac surgery at one of New Zealand's principal hospitals ${ }^{206}$ and the previous Government's pharmaceutical agency recently faced judicial review proceedings over its decision to deny funding for certain types of early breast cancer treatment. The High Court acknowledged that the agency had failed to properly consult the public, and other interested parties, prior to making its decision to deny the pharmaceutical supplier's application for funding 12 months of Herceptin treatment. ${ }^{207}$ Concerns have also been raised because individuals are expected to "part-pay" for their visits to a general practitioner, placing a financial barrier to primary healthcare for those on low incomes. Finally, the most recent concluding observations of the ICESCR Committee highlighted the need for the Government to "strengthen its efforts to ensure equitable access to health services in both rural and remote areas." 208

\section{Discrimination in the receipt of healthcare and discrepancies in health status}

Evidence has shown that economic, social and cultural factors have some impact on whether or not an individual will experience good or bad health. A number of groups have been identified as being particularly vulnerable, including those with low incomes, the elderly, refugees and asylum seekers, children, and Māori and Pacific peoples. Measures taken to improve the health status of some of these vulnerable groups include the introduction of the Māori and Pacific health action plans in 2002 and $2003^{209}$ and the 2003 child health strategy. ${ }^{210}$ In addition, refugees and asylum seekers are eligible for publicly funded health services in New Zealand.

205 For parliamentary questions relating to health see www.parliament.nz/en-NZ/PB/Debates/QOA (accessed 18 February 2008). The case of Rau Williams in 1997 focussed public interest on this issue. Although allegations were made that the decision not to provide life-saving dialysis treatment to Mr Williams was based on financial constraints, the Court of Appeal found that the decision was made in the belief that it was in the best clinical interests of Mr Williams. See Shortland v Northland Health Ltd [1998] 1 NZLR 433.

206 See "Minister faces deaths over hospital waiting list" New Zealand Herald www.nzherald.co.nz/section/1/ story.cfm?c_id=1\&objectid=10492296 (accessed 22 February 2008).

207 Walsh and others v Pharmaceutical Management Agency [2008] BCL 417 paras 201-204. However, the challenge to the agency's decision agreeing to fund early stage treatment with Herceptin for nine weeks, and the decision declining to grant funding approval for provision of Herceptin in exceptional circumstances to individuals who otherwise would not qualify for funded treatment failed. The National-led Government has announced that it intends to honour its election promise to fund a twelve-month course of the drug. See http://beehive.govt.nz/release/government+honours+herceptin+promise (accessed 5 February 2009).

208 Committee on Economic, Social and Cultural Rights Report (26 June 2003) E/C.12/1Add.88 para 34.

209 The Pacific Health and Disability Action Plan (2002) and He Korowai Oranga and Whakatataka-The Mãori Health Action Plan (2003) produced by the Ministry of Health.

210 A Child Health Strategy was also produced by the Ministry of Health in 1998. These are available at www.moh.govt.nz/childhealth (accessed 21 February 2008). 
However, disparities in health status continue to exist. For example, while life expectancy continues to improve for most Pakeha, Māori and Pacific peoples continue to experience disproportionately high morbidity and premature mortality, ${ }^{211}$ causing the ICESCR Committee to request that "New Zealand adopt effective measures to improve the health situation of the indigenous Māori population." 212 Further, initiatives on children's health have not adequately addressed problems with drugs and alcohol among adolescents, nor have they dealt with high rates of suicide and teenage pregnancy of young New Zealanders. ${ }^{213}$

Disparities also persist for refugees and asylum seekers who are eligible to receive health care in New Zealand, but for whom effective access to health services remains restricted in practice because of language difficulties and a general lack of awareness and understanding about the availability of health services. In addition, following an inquiry into discrimination experienced by transgender people, the Human Rights Commission highlighted the need for improvements in access to health services for this vulnerable group, particularly in relation to the provision of gender reassignment services. ${ }^{214}$ Finally, the High Court has recently dismissed a claim alleging that the provision of health care under the ACC scheme unlawfully discriminates on the grounds of disability against those who are in need of health care which did not arise from an accident or other ACC covered cause (in this case disability arising from multiple sclerosis). ${ }^{215}$

\section{The Right to Pre-Conditions for Good Health}

Health status is strongly influenced by factors outside of primary health care considerations and this is recognised in the scope of the right to health. Pre-conditions for good health include education about health, efforts to prevent bad health and the supply of certain conditions to provide a platform for well-being.

Specific action promoting the pre-conditions for good health is regularly taken in New Zealand. A variety of governmental organisations have responsibility for promoting the pre-conditions for good health, including the Ministry of Health and District Health Boards. ${ }^{216}$ Wider health

211 Human Rights Today, above n 15, 6.

212 Committee on Economic, Social and Cultural Rights Report 26 June 2003 E/C.12/1Add.88 para 33.

213 Ibid, para 31.

214 Human Rights Commission To Be Who I Am (2007) www.hrc.co.nz/hrc (accessed 18 February 2008).

215 Trevethick $v$ Ministry of Health [2008] NZAR 454.

216 Some examples of this include legislation for a smoke free environment, such as the Smoke-free Environment Amendment Act 2003, which banned smoking in workplaces, including bars and restaurants in order to promote public health; the development of strategies which advocate for a healthier environment for children such as the Child Health Strategy www.moh.govt.nz/childhealth (accessed 21 February 2008); and the promulgation of regulations (in 1978 and 1983) in response to the growing scientific certainty of the link between asbestos exposure and lung cancer. 
protection measures are also taken regarding the quality of water, food, air, land, and adequate sanitation in order to promote general well-being. The management of such services is overseen largely by local government bodies which have express responsibility for promoting the social, economic, environmental, and cultural well-being of communities, in the present and in the future. $^{217}$

\section{Other Rights Relating to Health Status}

Section 21 of the HRA recognises a range of health factors as prohibited grounds of discrimination, including physical and psychiatric illness, disability, and the presence in the body of organisms capable of causing illness. ${ }^{218}$ To date, the litigation generated under this section has centred on disability discrimination. ${ }^{219}$ BORA also recognises the right not to be deprived of life, the right not to be subjected to medical or scientific experimentation and the right to refuse to undergo medical treatment. ${ }^{220}$

\section{ENVIRONMENT}

The right to an environment of a particular quality can be described as an emerging right. The right to an environment is not explicitly protected in any international human rights instrument, although a number of rights in the international framework support the right to an environment. The right can however be seen as implicit in the rights to an adequate standard of living and health. There is also a wide body of international environmental law establishing regulatory frameworks for

217 Local Government Act 2002, s 77.

218 HRA 1993, s 21(1)(h). Other health-related prohibited grounds of discrimination are: disability, including physical disability and impairment; intellectual or psychological disability or impairment; any other loss or abnormality of psychological or anatomical structure or function; reliance on a guide dog, wheelchair or other remedial means.

219 See for example New Zealand Amalgamated Engineering Printing and Manufacturing Union $v$ Air New Zealand Ltd [2004] 1 ERNZ 614 (Emp Ct) where the plaintiff argued unsuccessfully that 'disability' under s 21(1)(h) should include a recreational drug habit; O'Loughlin v Hodgson [1993] 2 ERNZ 265 (Emp Tribunal) where the plaintiff successfully complained of an unjustified dismissal due to discrimination based on her having diabetes; Wilson v Sleepyhead [1992] 3 ERNZ 614 (Emp Tribunal) where the plaintiff was found to have been unjustifiably dismissed due to his epilepsy; Warr v Elizabeth Arden (NZ) Ltd (3 August 1999) HC AK CP 394/97 where a plaintiff failed to prove his condition of stress and depression came under the meaning of disability in s 21(1)(h); Morrison v Housing New Zealand Corporation (8 December 2006) HRRT 14/06 where the plaintiff claimed against the defendant on his uncle's behalf, where the uncle suffered a disability; the claim was struck out due to lack of causation; and Attwood v Imperial Industries (25 October 1991) Emp Relations Authority, Wellington WA 72/01 where the plaintiff was successful in a claim for unjustifiable dismissal based on her health condition.

220 BORA, ss 8, 10 and 11. For cases relating to these rights see Auckland Healthcare Services Ltd v L \& L (1998) 17 FRNZ 376; Shortland v Northland Health Ltd [1998] 1 NZLR 433 and Auckland Health Board v Attorney-General [1993] 1 NZLR 235. 
various natural resources. The developing right to an environment is likely to have particular significance for New Zealand as well as for the wider Pacific. ${ }^{221}$

\section{A Legal Framework}

New Zealand's environmental law has, over the past forty years, become increasingly sophisticated. New Zealand's environmental and resource management law is now governed by a complex mixture of legislation, case law, and international law. ${ }^{222}$ The environmental law framework can best be understood against the background of the key biophysical aspects that comprise New Zealand's environmental profile. Due to geographic isolation, New Zealand's ecosystems are abundant with unique species with more than 80,000 species of flora and fauna. ${ }^{223}$ In terms of geographical features, New Zealand has one of the longest coastlines in the world, numerous mountains, lakes, rivers and geothermal areas. ${ }^{224}$ These diverse ecosystems and natural resources are in the most part managed by the Resource Management Act 1991 (RMA). In recognition of this diverse and important set of resources, Part II of the RMA requires that preservation of the natural character of the coastal environment, wetlands, lakes and rivers, protection of outstanding natural features and landscapes, protection of indigenous vegetation and fauna, and the maintenance of public access to marine areas, lakes and rivers, are considered as matters of national importance.

When it was enacted, the RMA heralded a new legal and managerial environmental framework which pioneered the sustainable management of physical and natural resources as the primary purpose. $^{225}$ This focus on sustainable management is essential due to factors such as increasing urbanisation and household consumption (despite a low overall population density). ${ }^{226}$

221 Justice Susan Glazebrook "Human Rights and the Environment" in this volume.

222 Nolan Environmental and Resource Management Law (3 ed, LexisNexis, Wellington, 2005) 32. For general information on the right to environment, see Advisory Council of Jurists APF Reference on the Right to Environment Observations and Recommendations (2008) http://asiapacificforum.net (accessed 7 April 2008) and Advisory Council of Jurists APF Reference on the Right to Environment Background Paper (2007) http://asiapacificforum.net (accessed 7 April 2008).

223 Ministry for the Environment Environment New Zealand 2007 www.mfe.govt.nz (accessed 8 February 2008) 38 [Environment New Zealand].

224 Ibid, 9.

225 RMA, s 5(1). Note the National-led Government has recently announced its intentions to reform the RMA. See http://beehive.govt.nz/sites/all/files/RMA_Amendments_Summary_Feb_2009.pdf (accessed 5 February 2009).

226 Environment New Zealand, above n 223, 40: New Zealand has a population of just over four million (an increase of 11 per cent since 1996). In 2003 New Zealand's ecological footprint was sixth highest in the OECD. New Zealanders' ecological footprint has increased from 19.9 global hectares in 1998 to 22.9 in 2004. 
The RMA attempts to address these sustainability issues by utilising broad purposive principles and policy statements rather than taking a prescriptive approach. ${ }^{227}$ In keeping with this tenor, the RMA regulates New Zealand's environmental development using complex zoning laws which are governed by a tiered system of policy statements and plans. ${ }^{228}$ At the highest level, the national policy statement delineates the objectives and policies of matters of national significance that are relevant to achieving the RMA's purpose. ${ }^{229}$ There are then regional policy statements, and regional and district plans. ${ }^{230}$

\section{Individual rights}

Neither BORA nor any other legislation contains a right to an environment of a particular quality (although perhaps a right to an environment could grow from the right to life in section 8 of BORA. $)^{231}$ The RMA, however, embodies a strong participatory ethos which allows individuals and groups affected to require the activity to be measured against regional plans. ${ }^{232}$ Although a right to an environment of a particular quality does not yet exist, the right to participate in environmental decisions is central and may support the emergence of a specific right to environment. ${ }^{233}$

2 Other sources of law

Following the enactment of the RMA, a raft of environmental statutes were enacted relating to the sustainable management focus. ${ }^{234}$ New Zealand also possesses a collection of conservation

227 Nolan, above n 222, 54.

228 RMA, Preamble.

229 RMA, s 45. At this level there are also national environmental standards and the New Zealand coastal policy statement.

230 Ibid, ss 59, 63 and 87.

231 Compare Supreme Court of the Philippines: Minors Oposa v Secretary of the Department of Environment and Rural Resources 33 ILM 173 (1994) Davide J Rj p 200 (224 SCRA 792 (1993)). The Supreme Court of Chile in Comunidad de Chañaral v Codeco División el Saldor (1998) S/Recurso de Protecion. The Corte Suprema held that there was a right to a clean environment due to Art 19 of the Constitution of Chile. APF Reference on the Right to Environment Observations and Recommendations 4 www.asiapacificforum.net (accessed 13 February 2008) [Reference on the Right to Environment].

232 RMA, ss 73, 93, 94, 96, 100. Hayward "Freshwater Management: Water Markets and Novel Pricing Regimes" (2006) 10 NZ J Envtl L 215, 228.

233 Reference on the Right to Environment, above n 231, 3.

234 These include the Biosecurity Act 1993, Maritime Transport Act 1994, Fisheries Act 1996, Hazardous Substances and New Organisms Act 1996, Energy Efficiency and Conservation Act 2000, Local Government Act 2002, Climate Change Response Act 2002, and the Land Transport Management Act 2003. 
legislation concentrating on various different living resources, geographic areas and statutes relating to biohazards. ${ }^{235}$

To complete the picture on sources of environmental law in New Zealand, it is important to note that successive New Zealand governments have entered into a growing number of international treaties involving the environment. ${ }^{236}$ Although not directly enforceable without domestic implementation, the RMA does incorporate international obligations into the decision-making process. $^{237}$

\section{B Current Issues in Environmental Law in New Zealand}

\section{Climate change}

There is now strong international support for the theory that certain gases cause an enhanced greenhouse effect. ${ }^{238}$ In recognition of this, New Zealand is a signatory to the United Nations Framework Convention on Climate Change (UNFCCC) and the Kyoto Protocol. ${ }^{239}$ The latter was given effect to via the Climate Change Response Act 2002. Under its commitment to the UNFCCC, New Zealand has undertaken to stabilise greenhouse gas concentrations to prevent dangerous interference with the climate system. ${ }^{240}$

To ensure compliance with Kyoto gas reduction targets, in 2008, Parliament enacted the Climate Change (Emissions Trading) Amendment Act to implement the New Zealand Emissions Trading Scheme (ETS). Under the ETS, New Zealand would have been a world leader by developing a multi-sector emissions trading scheme applying to several gases. ${ }^{241}$ However, following the November 2008 election, a key aspect of the confidence and supply agreement reached between National and Act parties was the agreement to establish a special Select Committee of Parliament to review the ETS and, further, to pass an amendment to the legislation delaying its

235 These include the Wildlife Act 1953, the Reserves Act 1977, National Parks Act 1980, Conservation Act 1987, and the Maritime Transport Act 1994.

236 See www.mfe.govt.nz for a list of major international agreements.

237 RMA, ss 45(2)(b), 58(f).

238 Hoffmann "The Role of Economic Instruments to Reduce Carbon Emissions and their Implementation: A Comparison of Environmental Policies in New Zealand and Germany" (2006) 10 NZ J Envtl L 129, 131.

239 United Nations Framework Convention on Climate Change (9 May 1992) 1771 UNTS 107 [UNFCCC]. New Zealand signed the UNFCCC on 4 June 1992. The Kyoto Protocol came into force in 2005. See UNFCCC Bali Action Plan www.unfccc.net (accessed 14 February 2008).

240 UNFCCC Art 2. Under the Kyoto Protocol, New Zealand must maintain a zero per cent increase in emissions from 1990 levels in the 2008-2012 period.

241 Hercus "Bold climate change announcements pose big legal questions for lawyers" 38 Law News (12 October 2007) 8. 
implementation. ${ }^{242}$ Although the proposed amendment has not been passed, Parliament has established a special Select Committee to review the ETS. ${ }^{243}$ The Minister for the Environment has stated that the new Government takes a "more modest view of New Zealand's role in the global efforts to tackle climate change", ${ }^{244}$ and the terms of reference for the special Select Committee are wide-ranging. ${ }^{245}$ The outcome of this review is expected later in 2009.

Climate change is predicted to cause significant land mass loss for coastal countries/islands and areas that are flood-prone. ${ }^{246}$ As a result, "environmental refugees" from affected areas (particularly the Pacific) may look to New Zealand for refuge. However, environmental refugees are unlikely to fit within the Refugee Convention grounds (race, religion, nationality, member of a particular social group or political opinion). ${ }^{247}$ No consensus on whether the definition of "refugee" ought to be changed has yet been reached. ${ }^{248}$

\section{Agriculture}

New Zealand's status as an agricultural economy means that nearly half New Zealand's greenhouse gas emissions are produced by the agricultural sector. ${ }^{249}$ Due to this unique agricultural focus, methane emissions and nitrogen emissions accounted for 48.5 per cent of New Zealand's total gross emissions in $2003 .{ }^{250}$ New Zealand is the only country which has incorporated the

242 www.national.org.nz/files/agreements/National-Act_Agreement.pdf (accessed 4 February 2009).

243 www.beehive.govt.nz/release/climate+change+select+committee+established (accessed 4 February 2009).

244 Ibid.

245 www.parliament.nz/en-NZ/SC/Details/EmissionsTrading/ (accessed 4 February 2009).

246 Hoffmann, above n 238, 131. Intergovernmental Panel on Climate Change Third Assessment Report Climate Change 2001: Synthesis Report www.ipcc.ch (accessed 24 January 2008) 15. Warnock "Small Island Developing States of the Pacific and Climate Change: Adaptation and Alternatives" (2007) 4 NZYIL 247,249 .

247 Convention Relating to the Status of Refugees (28 July 1951) 189 UNTS 150, Art 1(2) [Refugee Convention]; see also Keane "The Environmental Causes and Consequences of Migration: A Search for the Meaning of 'Environmental Refugees"' (2004) 16 Geo Int'l Envtl L Rev 209, 215 and Black "Environmental refugees: myth or reality?" New Issues in Refugee Research Working Paper No. 34, provided for UNHCR, 11 www.unhcr.org (accessed 22 December 2007).

248 Warnock, above n 246, 249 and 265; Keane, above n 247, 215 who suggests that the Refugee Convention should be brought into line with the right to seek safety in Art 14 of the UDHR; Black, above n 247, 11; and Lopez, "The Protection of Environmentally-Displaced Persons in International Law" (2007) 37 Envtl L 365.

249 Hoffmann, above n 238, 132. In contrast it makes up 12 per cent of most other developed countries' emissions: see Ministry of Agriculture and Forestry Agriculture in a New Zealand Emissions Trading Scheme www.maf.govt.nz (accessed 31 January 2008).

250 Ministry of Agriculture and Forestry Review of Climate Change Policies: New Zealand Domestic Context http://mfe.govt.nz (accessed 4 February 2008) 60. 
agricultural sector in a domestic ETS but under the 2008 package, agricultural non-carbon dioxide emissions are exempt from any emissions charges or other compulsory mitigation measures until 2012. ${ }^{251}$

Agriculture also contributes heavily to water quality issues due to leaching of residue such as fertiliser and animal excrement into the waterways. ${ }^{252}$ These agricultural water quality issues are often referred to as "non-point source discharges" (NPSDs). ${ }^{253}$ Although section 15 of the RMA has been effective to manage point source discharges, ${ }^{254}$ there has been little effort to use this section to cover NPSDs. ${ }^{255}$

In June 2008, however, a national environment standard for sources of human drinking water will be operational and a Strategic Framework For Dairy Farming Future 2005-2015 has been produced to help deal with these issues. ${ }^{256}$ Furthermore, the Health (Drinking Water) Amendment Act 2007 comes into effect on 1 July 2008 and requires suppliers of drinking water to take all reasonable steps to comply with the drinking water standards, to implement risk management plans, and take reasonable steps to protect water sources from contamination.

\section{Energy production in New Zealand}

One notable feature of New Zealand's emissions profile is the low level of emissions represented by carbon dioxide production from the energy sector which demonstrates the prime role of renewable energy sources in New Zealand. ${ }^{257}$ In keeping with the focus on sustainable energy, the Climate Change Response (Emissions Trading) Amendment Act 2008 imposed a moratorium on new fossil-fuelled baseload thermal electricity generation, except to the extent necessary to ensure the security of New Zealand's electricity supply. ${ }^{258}$ Along with other aspects of the ETS, this is, however, now under review by the Emissions Trading Scheme Select Committee.

251 Ministry of Agriculture and Forestry, above, 91.

252 Ministry for the Environment Environment New Zealand 2007 Summary www.mfe.govt.nz (accessed 13 February 2008) 48 and Drummond "Managing the Environmental Effects of Agriculture under the Resource Management Act: Non-point Source Discharges" (2006) 10 NZ J Envtl L 255.

253 Drummond, above n 252, 264.

254 Point source discharges have a readily identifiable discharge point such as a sewer.

255 Drummond, above n 252, 264.

256 Previously no national standards for water existed so regional councils were left to regulate: see ibid, 264; Ministry for Environment www.mfe.govt.nz (accessed 14 February 2008).

257 Ministry of Agriculture and Forestry, above n 245, 61. Renewable energy use was at 66 per cent in 2005: Environment New Zealand 2007 Summary, above n 248, 23.

258 Climate Change Response (Emissions Trading) Act 2008, s 73. 


\section{Indigenous rights}

In recent years the principles of the Treaty of Waitangi have come to play an increasing role in environmental and resource management law. ${ }^{259}$ Under Article 2 of the Treaty, Māori are guaranteed full, exclusive and undisturbed possession of their lands, estates, forests, fisheries and other properties. One of the consequences of this is that Treaty principles must be taken into account in environmental decision-making. This is demonstrated in section 8 of the RMA where it is stated that all persons exercising functions and powers under the RMA, in relation to managing the use, development, and protection of natural and physical resources, shall take Treaty principles into account. ${ }^{260}$ It has, however, been held by the High Court that section 8 confers no duty of consultation on applicants for resource consent. ${ }^{261}$

Section 7 of the RMA states that "kaitiakitanga" must also be considered. Māori define this as "guardianship" and stewardship. ${ }^{262}$ Guardianship is also linked to the intangible spiritual and cultural aspects of land and other resources. ${ }^{263}$ However, it has been held in several cases that intangible adverse effects on Māori spiritual and cultural aspects cannot always constitute a trump card in the absence of visible adverse physical effects on the resource. ${ }^{264}$

Another topical issue that involves Māori interests in the environment is the Treaty of Waitangi claim known as the Flora and Fauna Claim or Wai 262. ${ }^{265}$ The claim seeks recognition and protection of comprehensive rights to indigenous flora and fauna and mātauranga Māori (traditional

259 New Zealand Māori Council v Attorney-General [1987] 1 NZLR 641: principles include partnership, consultation, duty to act reasonably and in good faith, active protection and duty to remedy breaches.

260 Other references to Treaty principles in the environmental context include the Crown Minerals Act 1991, Environment Act 1986, and Conservation Act, s 4.

261 Carter Holt Harvey Ltd v Te Runanga o Tuwharetoa Ki Kawerau [2003] 2 NZLR 349 para 55. The new s 36A of the RMA, which states that consultation is not required by either an applicant or consent authority in relation to a resource consent application (although there may be a duty to consult under other legislation), has created some uncertainty due to conflict with ss 6 and 8 of the RMA which state that "all persons exercising functions and powers" under the Act must take Māori interests and Treaty principles into consideration. It is questionable if this can be achieved without consultation with Māori: see Vince "Māori Consultation Under the Resource Management Act and the 2005 Amendments" (2006) 10 NZ J Envtl L $295,302$.

262 Milne Handbook of Environmental Law (Royal Forest and Bird Protection Society, Wellington, 1992$) 514$.

263 Bleakeley v Environment Risk Management Authority [2001] 3 NZLR 213 (HC).

264 Resource Management (looseleaf last updated November 2007) A8.06(6) and (7). There is no general right of veto accorded to Māori: Watercare Services Ltd v Minhinnick [1998] 1 NZLR 294.

265 Ministry of Economic Development Information Sheet: Treaty of Waitangi Claim Wai 262 http://med.govt.nz (accessed 2 February 2008). 
knowledge) as taonga protected by Article 2 of the Treaty. ${ }^{266}$ This claim demonstrates the close interaction of environmental law and indigenous rights.

\section{Intrinsic value}

New Zealand legislation has followed an ecocentric approach to the environment which emphasises the idea that "nature has a value in its own right". ${ }^{267}$ The rationale is that the delicate balance of an ecosystem depends on the homeostatic existence of all natural parts of the ecosystem. However, in both the Conservation Act 1987 and the RMA the definition of natural resources recognised for their intrinsic value includes introduced species. ${ }^{268}$

\section{CONCLUSIONS}

New Zealand has a reasonably strong human rights report card, although there is cause for concern in a number of areas, particularly in terms of the human rights of the Māori population. In terms of the five focus areas of this report, some concluding comments on each can be made.

First, New Zealand's commitment to rule of law is generally strong. There are, however, currently some concerns in terms of access to justice. Two systemic issues of particular note are the impact of legal aid rates on realisation of the right to a lawyer, and excessive delays in some court proceedings.

The second area of focus was culture and language. Recent positive developments in terms of language are the enactment of the 2006 New Zealand Sign Language Act, and the growth in the number of Māori who can speak, read, write and understand te Reo Māori. Of concern is the survival and continued use of various Pacific languages in New Zealand; the Tokelau, Cook Islands Māori and Niue languages are particularly vulnerable because of low numbers of speakers. In terms of culture, ongoing priority issues are the human rights of Māori, including how to give meaningful effect to the principles of the Treaty of Waitangi in the modern world. A recent disappointment was New Zealand's September 2007 vote against the United Nations Declaration on the Rights of Indigenous Peoples.

In the third area of education, although the right to education is generally secured, there are some areas of concern. While participation rates in early childhood, primary and secondary education are relatively high, the difference in participation and achievement rates between low and

266 Tane Waetford "Traditional Knowledge" [2007] NZLJ 263. Submissions completed June 2007.

267 See these Acts for ecocentric focus: National Parks Act 1980, s 4(1), Hauraki Gulf Marine Park Act 2000, s 32(b), Environment Act 1986 (long title), Conservation Act 1987, s 2; RMA, s 7.

268 Curran "The Preservation of the Intrinsic: Ecosystem Valuation in New Zealand" (2005) 9 NZ J Envtl L 51, 75. This definition creates difficulties in terms of pest eradication and population management - for example the kiore rat from the Hauraki Gulf Islands and the Kaimanawa horses in the Tongariro National Park. 
high decile schools and among some ethnic groups is marked. Groups of particular vulnerability are disabled and special needs students, Māori and Pacific students, and non-citizen children. In the gender area, a recent focus is on the achievement disparity of boys. There are also some concerns around the current university funding structure which may lead to limits on intakes of undergraduate students and so result in universities of the elite. Another recent development is the increase of religious controversies in schools.

New Zealand's health services are generally favourable in terms of international standards. New Zealand's Health and Disability Commissioner has however recently described New Zealand hospitals as having unacceptably low safety standards. In terms of the allocation of resources within the health sector, concern has been expressed in relation to access to timely surgical treatment and the availability of suitable medicines for life threatening illnesses. Groups of particular vulnerability in realising the right to health are those with low incomes, the elderly, refugees and asylum seekers, children, and Māori and Pacific peoples. In terms of discrimination, New Zealand legislation prohibits discrimination on various health-related grounds, and the area where most litigation has arisen to date is disability discrimination.

Finally, although New Zealand's legal framework does not recognise the right to an environment of a particular quality, the 1991 Resource Management Act provides for a strong participatory framework, based on sustainable management, for regulating environmental use. New Zealand legislation has also tended to follow an ecocentric approach to the environment which emphasises the idea that nature has a value in its own right. New Zealand is currently engaged in determining its legal and policy framework for responding to climate change. Protecting and promoting indigenous rights in the environmental context remains an ongoing challenge. 